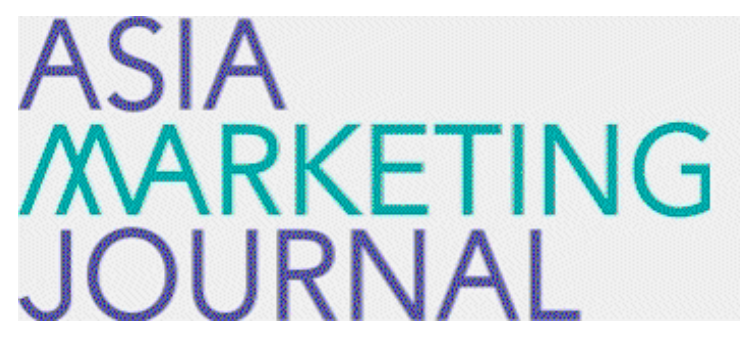

ASIA MARKETING JOURNAL

Volume 5 | Issue 2

Article 2

6-25-2003

\title{
마케팅의 경험적 접근방법 및 그 활용방안에 관한 비판적 고찰
}

지ㄴㅛㅛㅇ 이

Follow this and additional works at: https://amj.kma.re.kr/journal

Part of the Marketing Commons

\section{Recommended Citation}

이, 진룡 (2003) "마케팅의 경험적 접 근방법 및 그 활용방안에 관한 비판적 고찰," Asia Marketing Journal: Vol. 5 : Iss. 2 , Article 2.

Available at: https://doi.org/10.53728/2765-6500.1105

This Article is brought to you for free and open access by Asia Marketing Journal. It has been accepted for inclusion in Asia Marketing Journal by an authorized editor of Asia Marketing Journal. 


\section{마케팅의 경험적 접근방법 및 그 활용방안에 관한 비판적 고찰*}

\section{A Critical Review of Some Experiential Approaches in Marketing and Their Applicability}

이진용(서울산업대학교 경영학과 부교수)

baleejyesnut.ac.kr

본 연구는 마케텅의 네 가지 경험적 접근방법, 즉 정보탐색적 접근, 브랜드 컨셉으로서의
경험, 즐거움의 경험, 총체적 경험 등의 내용을 살펴보고 이들의 기여와 문제점 및 한계를
살펴보았다. 또한, 감성적 경험과 소비 시점의 경험에 관해서도 논의하였다. 경험적
접근방법은 새로운 마캐팅 수단으로 충분한 잠재력을 가지고 있으며 인지적 접근, 브랜드의
기능적 혜택을 강조하는 기존 마케팅 방식과는 상당한 차이가 있다. 하지만, 경험적
접근방법 앞으로 해결해야 할 많은 과제가 남아 있으며, 일부 실무적인 서적들이 주장한
바와 같이 인지적, 기능적 마케팅 방식을 대체하는 것은 아니라고 할 수 있다. 기존
전통적인 마케팅 방식에 대하여 보완적 역할을 수행할 수 있으며, 제한적인 조건에서만
적합한 방식으로 평가할 수 있다.

• 논문접수 : 03.04 게재확정 : 03.06 


\section{1. 서론}

기업들이 마케팅 활동을 수행하면서 과거에 비하여 경험적 접근 방법을 점차 많이 사용하고 있다(Hirshman and Holbrook 1982, Holbrook and Hirshman 1982, Pine and Gilmore 1999, Schmitt 1999, 2003). 패션 제품에 속하지 않는 다양한 제품군에서도 프리미엄급 브랜드들은 세련되고 멋지고 개성적인 디자인을 추구하고 있으며 소비자들에게 감각적이고 미학적인 경험을 제공하는 것을 목표로 삼고 있다. BMW Z8는 웹 사이트(http://www.bmw.com/bmwe/products/automobiles/28)에서 "강력하고, 영감을 고취시키고, 독특한(powerful, inspiring, unique)" 점을 자신의 특성으로 제시하고 있다. 하지만, Z8이 다른 브랜드와 가장 차별화되는 점은 역시 소비자들이 특이하고 세련된 디자인에서 느낄 수 있는 브랜드에 대한 감성적 경험이다.

경험을 마케팅의 초점으로 끌어들이는 현상은 인터넷 분야를 중심으로 하여 급속도로 확산되고 있다. 인터넷 접속 속도가 향상되면서 정보 제공 방식이 문자 위주에서 시각적인 그래퍽으로 전이되었고, 디자인을 이용하여 감각적 경험을 제공하는 것이 훨씬 용이해졌다. 최근 들어 음성 정보까지 추가되어 시각과 청각을 망라하는 총체적이고 진정한 경험(holistic and authentic experience)을 제공하기 시작하였다(Carpenter 2000). 온라인 계임, 도박, 경매 사이트들은 소비자와 대상이 하나가 되는 느낌을 받는 '합일감'(flow, Csikszentmihalyi 1975, 1990 , Hoffman and Novak 1996)의 경험을 제공하기 위하여 많은 노력을 기울이고 있다.

Pine과 Gilmore(1998, 1999), Schmitt(2003) 등은 앞으로 경제 전반과 마케팅 분야에서 경험적 요소가 기업 경쟁력의 근간이 될 것이라고 호언하고 있다. 이들의 말처럼 소비생활에서 경험적 요소가 크게 부각되는 현상을 사회 도처에서 관찰할 수 있다. 소비자들은 이전에 비하여 영화, 디자인, 음악, 드라마 등 엔터테인먼트 분야나 스포츠, 게임 등 놀이활동에 상당한 관심을 보이고 있으며, 일상적인 소비생활에서도 미적 감각, 즐거움이나 짜릿한 느낌을 추구하고 있다. 특히 젊은 충들에게 이러한 현상이 두드러지게 나타나고 있으며, 이들 집단은 거의 모든 소비 활동에서 경험적 요소를 중요시 하는 성향을 보이고 있다.

한편, 경험적 접근방법이 실무적인 브랜드 구축방법으로 각광을 받아 급속히 확산되고 있지만, 학계에서는 이에 대한 평가를 거의 수행하지 못한 상태이다. 경험적 접근방법이 어떤 점에서 마케팅 학계와 실무분야에 기여하였고, 또 이를 활용하는 데에 어떤 제약요건이 있으며 아직 해결되지 않은 문제는 어떤 것인가 등에 대하여 연구가 거의 수행되지 못한 편이다.

따라서, 실무적인 취향의 경험적 접근방법(예를 들어, Pine and Gilmore 1999, Schmitt 1999 등)에 대한 평가는 크게 엇갈린다. '귝단적인 비판 혹은 찬사', 혹은 '적당주의적인 타협안' 둥의 평가가 나타나고 있다. 즉, 일부 학자들은 논리적 분석도 없이 근거 없는 주장으로 일축하기도 하고 일부 실무 담당자들은 마치 만병통치약을 발견한 듯한 극찬을 아끼지 않기도 한다. 예를 들어 한 실무자는 "Schmitt의 이론은 수 년 전부터 미국에서 제3세대 브랜드 마케팅 컨셉이라는 찬사를 받고 있다" 등의 표현울 서슴지 않고 제시하고 있다. 한편, 또 다른 학자들은 경험적 접근방법을 포함한 어떤 주장이고 맞을 때도 있고 그렇지 않을 때도 있다는 막연한 평가만을 내리고 있다.

경험적 접근방법에 대한 논의가 크게 부족한 것은 경험의 정의에 대한 견해가 지나치게 
다양하여 연구를 수행하는 데에 상당한 장애요인이 되었기 때문인 것으로 파악된다(경험의 다양한 정의와 분류방법에 대해서는 이진용 2003을 참조하시오). 따라서, 본 연구에서는 경험적 접근방법과 관련된 4가지 유형에 한정하여 논의를 수행하고자 한다. 각 경험적 접근방법에 대한 비판적 고찰을 퉁하여 세부적인 주장들을 분석하고자 한다. 또한, 경험적 접근방법이 기존 브랬드관리를 대체할 수 있다는 견해(Pine and Gilmore 1998, Schmitt 1999)를 평가하고자 한다. 학계의 기존 연구들은 경험적 접근이 인지적 접근방법이나 브랜드 기능적 특성을 강조하는 방법에 대하여 보완적이거나 일부 조건에서만 적합한 방법이라는 견해를 가지고 있지만, 실무적인 접근 방법들은 시대의 추세에 의하여(Pine and Gilmore 1998), 흑은 총체적 경험 제공이 브랜드 구축의 가장 중요한 요소이기 때문에(Schmitt 1999) 경험적 접근방법이 전통적 마케팅방식을 대체할 것이라고 주장하고 있는 실정이다. 이러한 실무적 접근방법들의 주장이 이론적으로 얼마나 타당성을 갖는가를 살펴볼 필요가 있다.

다음에서는 경험에 대한 네 가지 관점, 즉, 정보탐색적 관점, 브랜드 컨셉의 한 유형으로서의 경험, 재미와 흥미 제공, 총체적 경험 등에 대한 내용을 살펴보고 각각의 기여도와 문제점 및 제약조건을 살펴보기로 한다. 또한, 경험에 대한 종합적 논의를 수행한 후에 실무적 시사점을 제시하고자 한다.

\section{2. 경험에 관한 네 가지 관점의 요약}

소비자행동 분야에서 수행된 대부분의 연구는 정보처리 및 의사결정 둥 '인지적 관점'(Fiske and Taylor 1982, Petty and Cacioppo 1981)을 연구 패러다임으로 삼아왔으며 이에 따라 정보처리이론(Bettman 1979 둥), 행동론적 의사결정이론 둥이 주류를 이루어 왔다(Bettman, Luce, and Payne 1998, Loewenstein 2001 등). 또한, 소비자들이 브랜드를 인지하고, 정보처리에 의하여 브랜드를 평가하고, 이를 선택하는 둥의 활동올 포함하는 '구매 이전 과정(prepurchase processes)'에 초점을 맞추어 왔다(Keller 1993, Strahilevitz and Loewenstein 1998).

마케팅 확계에서는 경험을 대체로 두 가지 관점에서 연구 대상으로 삼았다. 먼저, 정보경제학 및 그 응용 연구들은 브랜드 혹은 제품에 대한 '정보탐색의 용이성'에 따라 탐색적 특성, 경험적 톡성, 신뢰적 특성 등으로 구분하고 있다(Ford, Smith and Swasy 1990, Nelson 1970). 이와는 다른 관점에서 수행된 연구들은 '브랜드가 제공하는 혜택'에 따라 기능적, 상징적, 경험적(혹은 정서적, 감성적) 범주로 구분하기도 한다(Aaker 1991, Park, Jaworski, McInnis 1986).

실무적으로는 즐거움의 경험과 총체적 경험 둥 두 가지 접근방법이 큰 호응을 얻고 있다. '즐거움의 경험'은 Czikszentmihalyi의 합일감이론(1975)을 기반으로 하여 Hoffman과 Novak(1996)이 온라인 경험에 관한 연구를 수행하고, Pine과 Gilmore(1997, 1999)가 경험경제의 개념을 제시하면서 크게 각광을 받았다. 이와 함께, 실무적으로 유행하던 개념인 '총체적 경험'에 대하여 Carpenter(2000), Hurst(1999), Schmitt(1999) 둥이 각자의 견해를 밝힌 바 있다.

위의 네 가지 관점은 기본적인 특성이 서로 상이할 뿐만 아니라, 다음과 같은 구체적인 차이점이 있어 이들에 대한 논의를 수행하는 것은 상당한 의의가 있다(각 접근방법의 특징은 표 1을 참조하시오). 
먼저, 앞으로 경헙적 접근방법이 인지적 접근방법을 대체할 수 있을 것인가에 대하여 실무적인 연구와 학계의 연구는 서로 상반된 견해를 보이고 있다. 학계에서는 경험을 인지적, 기능적, 혹은 정보탐색적 요소와 함께 브랜드 구축을 위한 여러 가지 방식의 한가지로 보고 있으며 경험적 접근은 특정 조건에서만 효율적인 방법이라는 견해를 보이고 있다(Aaker 1996, Ford, Smith, and Swasy 1990, Holbrook and Hirshman 1982, Keller 1993, Park, Jaworski, and MacInnis 1986, Park, Milberg, and Lawson 1991, Wright and Lynch 1995). 실무에서는 경험적 접근이 인지적 접근이나 기능적 특성 중심의 접근방법을 대체하거나 우월한 것으로 파악하여 기존의 마케팅 방식을 버리고 경험적 접근방법을 적극적으로 활용할 필요가 있다고 주장하고 있다(Pine and Gilmore 1998, Schmitt 1999).

한편, 학계의 두 가지 접근방법은 서로간에 상당한 차이를 보이고 있다. 정보탐색 관점(Ford et al. 1990, Nelson 1970 등)은 소비자 의사결정 단계를 중심으로 톡성이나 속성울 파악할 수 있는 시점에 따라 분류하고 있으며, 브랜드 컨셉의 유형으로 보는 관점(Keller 1993, Part et al. 1986 등)은 의사결정 단계와는 상관 없이 소비자들이 중요하게 생각하는 혜택을 중심으로 분류하고 있다.

두 가지 실무적인 접근방법에 대해서도 세부적인 견해 차이를 쉅게 관찰할 수 있다. 경험을 흥미와 재미로 보는 관점(Pine and Gilmore 1998)에서는 사회와 경제 현상의 변화에 의하여 소비자들이 줄거움을 추구하고 있어 경험의 중요성이 높아지기 때문에, 기업의 마케팅 활동의 핵심도 이 방향으로 이행하여야 한다고 주장하고 있다. 이에 비하여 총체적 경험을 중시하는 관점(Schmitt 1999)에서는 인지, 감각, 감성, 행동, 관계 둥 여러 가지 요소를 함께 포함하는 포괄적인 경험(혹은 게시탈트적 경험)이 브랜드 구축에 가장 영향력이 있다는 견해를 보이고 있다.

<표 1: 네 가지 경험적 접근방법의 특징 요약>

\begin{tabular}{|l|l|ll|}
\hline $\begin{array}{l}\text { 네 가지 } \\
\text { 접근방법 }\end{array}$ & $\begin{array}{l}\text { 브랜드, 속성, 소비자 } \\
\text { 반웅의 분류 기준 }\end{array}$ & 경험의 위상 & \\
\hline 정보탐색 관점 & $\begin{array}{l}\text { 소비자 의사결정단계 중 } \\
\text { 정보탐색이 가능한 시점 }\end{array}$ & $\begin{array}{l}\text { 탐색적, 경험적, 신뢰적 속성 등의 } \\
\text { 한가지 유형 }\end{array}$ \\
\hline $\begin{array}{l}\text { 브랜드 컨셉으로서의 } \\
\text { 경험 }\end{array}$ & $\begin{array}{l}\text { 소비자에게 제공하는 } \\
\text { 혜택의 유형 }\end{array}$ & $\begin{array}{l}\text { 기능적, 상징적, 경험적 브랜드 컨셉 중 } \\
\text { 한가지 유형 }\end{array}$ \\
\hline 즐거움의 경험 & $\begin{array}{l}\text { 경제의 발전단계에 따른 } \\
\text { 제품의 진화과정 }\end{array}$ & $\begin{array}{l}\text { 팡품, 제품, 서비스, 경험 둥 기업의 } \\
\text { 제공물 중 최종적 단계로 가장 } \\
\text { 부가가치가 높음 }\end{array}$ \\
\hline 총체적 경험 & $\begin{array}{l}\text { 모든 소비자의 반응이 } \\
\text { 경험 경험을 여러 유형의 한가지로 보지 않고 } \\
\text { 감각, 감성, 이성, 행동, 관계 및 이들을 } \\
\text { 포함하는 총체적 경험을 모두 포함 }\end{array}$ \\
\hline
\end{tabular}

\section{1 정보탐색 관점의 경험}

정보탐색적 관점에서는 경험(엄밀히 말하면 브랜드의 직접 경험)이 브랜드 속성 분류의 한가지 유형이다. 정보경제학의 브랜드 특성 분류(Nelson 1970)롤 받아들여서 구매의사결정과정의 어떤 시점에서 정보를 파악할 수 있는가에 따라 브랜드의 특성을 
구분한다. 즉, 정보탐색의 용이성에 따라 탐색적 특성(search characteristics), 경험적 특성(experience characteristics), 신뢰적 특성(credence characteristics) 등으로 구분한다(Ford, Smith, and Swasy 1990, Smith and Swinyard 1988, Wilkie 1994).

탐색적 속성은 그 특성을 정보탐색 과정이나 쇼평과정 등 구매 이전에 파악할 수 있는 것으로 패션제품의 스타일 등올 포함한다. 경험적 속성은 직접 사용해 보아야 알 수 있는 특성으로 음식의 맛 둥이 해당된다. 신뢰적 속성은 수술 시점의 내부 신체기관 봉합의 질과 같이 수술 후에도 품질에 대하여 정확히 평가하기 어려운 특성을 의미한다.

이와 같은 속성의 분류는 철저히 정보처리적인 관점에서 경헙을 언급하고 있다는 점을 유념할 필요가 있다. 전적으로 어떤 시점에서 브랜드 속성을 정확히 알 수 있는가에 따라 분류가 이루어지며, 속성이 감각적, 감성적, 상징적인가 아니면 기능적인 특성을 가지고 있는가는 고려하지 않는다. 따라서, Holbrook과 Hirshman(1982), 혹은 Park, Jaworski, McInnis(1986) 둥의 연구들과 같이 혜택의 종류에 따라 분류한 속성의 유형들과는 상당한 차이가 있다.

정보경제학의 제품/속성 분류는 소비자 의사결정단계와 연결할 수 있다. Engle, Blackwell, Miniard 둥(1997)은 소비자 의사결정단계를 문제인식, 정보탐색, 구매 전 평가, 구매, 구매 후 만족/불만족 둥 5 단계로 구분하고 있다. 구매 단계를 기준으로 문제인식, 정보탐색, 구매 전 평가, 구매 둥의 단계에서 브랜드의 측성이나 속성을 파악할 수 있으면 탐색적 속성, 그리고 구매 후 소비 단계에서 이를 알아낼 수 있는 것이라면 경험적 속성으로 분류할 수 있다. 이러한 과정을 모두 거쳐도 알 수 없는 특성은 신뢰적 속성으로 구분할 수 있어 기본적인 원리는 유사하다.

비숫하게 Ariely와 Carmon (2000), Kahneman과 Snell(1993)의 연구에서도 기대효용(expected utility)과 경험효용(experience utility)을 비교하였다. 기대 효용은 대상을 경험하기 이전에 소비자들이 예측하고 평가한 효용이고 경험효용은 직접적으로 경험하면서 느낀 효융을 의미하나다. 이들의 연구에서는 환자들의 고통 등 경험적 속성에 대하여 미리 얻은 객관적 수치를 이용하여 기대효용을 예측하고 이를 실제로 웅답자들이 답한 경험효용과 비교하였다 약간 다른 관점에서 Soman(2003)은 사람들은 시간적 거리(temporal distance)를 중시하기 때문에 동일한 경험에 대해서도 과거에 대한 회고적(retrospective) 시점과 미래에 대한 예측적(prospective) 시점의 평가에 따라 결과에 차이가 나타난다는 실증 결과를 제시하였다.

\section{2 브랜드 컨셉으로서의 경험}

Park, Jaworski, MacInnis 둥(1986)은 브랜드 의미(brand meaning)의 개념을 발전시켜 브랜드 컨셉 및 이미지 관리에 관한 논문을 발표하였다. Park 등의 연구에 의하면 브랬드는 기능적, 상징적, 경험적 이미지를 이용하여 포지셔넝을 수행할 수 있다. 기능적 혜택은 제품의 품질, 속성, 기능 둥 물리적인 특성을 통하여 소비자가 브랜ㄷ에서 얻을 수 있는 효익이다. 상징적 혜택은 소비자들의 신분이나 자신이 속해 있는 집단(연령충, 직업군, 동호인 둥)에 대한 소속감과 관련이 있다. 경험적 혜택은 장난감이나 게임과 같이 소비자들이 제품올 사용하면서 느낄 수 있는 다양한 형태의 감정을 얻는 것이다.

Park 등(1986)은 강력한 브랜드 이미지를 구축하기 위해서는 장기적인 관점에서 이미지를 유지하는 일관성 있는 포지셔닝 전략이 필요하고 주장하였다. 기능적, 상징적, 경험적 이미지 둥 서로 다른 유형들을 복합하여 사용할 경우에는 소비자들에게 혼란만 주어 경쟁 
브랜드에 비하여 명확한 이미지를 구축하기 어렵기 때문이다.

이와 비숫하게 Aaker(1995)는 브랜드 아이덴티티 시스템의 하나인 가치 제안(value proposition)을 기능적(functional), 감성적(emotional), 자기표현적(self-expressive) 혜택 둥으로 제시하였는데, 기본적인 특징은 Park 둥의 연구에서 제시한 브랜드 컨셉(혹은 혜택)과 유사하다. Aaker and Joachimsthaler(2000)에서는 기능적 혜택을 "그 브랜드는 어떤 것인가(What the brand is)", 그리고 정서적 혜택과 자기표현적 혜택을 “그 브랜드가 무엇을 하는가(What the brand does)"로 표현할 수 있다고 하였다.

Holbrook과 Hirshman(1982)은 소비자 행동의 연구방법을 인지적 접근과 경험적 접근방법의 두 가지로 분류하면서 상징적, 쾌락적, 감각적, 미적 요소들을 모두 경험의 범주에 포함하였다. Park 둥의 연구에서는 각 유형의 브랜드 컨셉에 따라 도입 단계, 정교화 단계, 강화 단계 둥 3 가지 단계에서 각각 어떻게 수행되어야 하는가에 대하여 견해를 제시하고 있다. Park 등(1986)은 각각 유형의 브랜드에 대하여 성장단계별로 전략을 제안하고 있다(세부적인 전략은 Park 등의 연구를 참조하시오).

\section{3 즐거움의 경험}

엔터테인먼트와 직접 관련이 있는 산업은 게임, 도박, 영화, 음악, 스포츠 둥 다양하다. 마케팅 학계에서는 과거에는 이러한 주제를 많이 다루지 않았지만, 최근 들어 영화와 관련된 수학적 모델 구축에 관한 연구를 수행하는 둥 많은 관심을 기울이기 시작하고 있다(Eliashberg and Sawhney 1994, Needlamegham and Jain 1999). 실무적으로는 엔터테인먼트 산업뿐만 아니라 인터넷 등 다른 산업에서도 '재미의 요소'에 대한 관심이 크게 높아지고 있다.

Hoffman과 Novak(1996)온 Csikszentmihalyi(1975)의 저서를 기반으로 하여 합일감(flow)을 '자신과 환경, 자극과 반웅, 과거, 현재, 미래가 일체가 되는 상황이 되면서 총체적인 감각이 나타나는 것'으로 정의하였다. Csikszentmihalyi에 의하면 행동을 유발하는 기회(도전)와 행동에 대한 능력(기술)이 충분하면서 서로 잘 조화될 때에 합일감(무아지경의 상태)이 나타난다. 합일감은 신나게 놀이를 하면서 거의 정신이 없는 어린아이들, 맞수간의 경기를 하는 운동선수, 온라인 컴퓨터 게임이나 채팅으로 밤을 새는 청소년들에게 나타난다.

Hoffman과 Novak의 연구는 수많은 인터넷 관련 기업들이 브랜드 경험에 대하여 관심을 갖도록 하는 데에 크게 기여하였다. 인터넷이 TV나 라디오 등의 매체에 비하여 능동적인 참여가 요구되는 매체라는 점에 근거하여, 많은 웹사이트들은 방문객들에게 합일감 혹은 이와 유사한 감정적 상태를 제공하기 위하여 많은 노력을 기울이고 있다. 정확한 의미의 합일감은 스포츠, 영화, 음악 등의 일부 매니어용 사이트, 그리고 채팅, 성인물 사이트 등에 만 나타나는 것으로 알려져 있지만, 인터넷 포탈사이트인 다음, 네이버, 야후, MSN 등도 웹 페이지에 카페를 개설하거나 할인 졔품을 광고하면서 즐거움과 홍미의 요소를 적극적으로 표현하고자 다양한 방법을 구사하고 있다.

Pine과 Gilmore(1999)는 경제가 발전하면서 즐거움을 추구하는 성향이 높아지기 때문에 이를 잘 활용하면 엄청난 부가가치를 창출할 수 있다고 주장하였다. 이들에 의하면 경제적 부가가치는 초기에 농산물이나 광물 둥 차별화가 가장 낮은 수준인 평상품(commodity)을 추출하는 것에서 시작하여 완제품(product)을 생산하는 것, 그리고 서비스(service)를 제공하는 행위, 마지막으로 가장 차별화되고 개인적인 수준의 경험(experience)을 무대에 을리는 
행위로 전이된다. 경제 수준과 차별화 단계가 높아질수록 부가가치는 기하급수적으로 향상한다.

Pine과 Gilmore가 제시한 평상품, 제품, 서비스, 경험의 예는 다음과 같다. 베이비 붐 세대들의 어린 시절에는 어머니가 생일파티를 위하여 케이크를 버터, 설탕, 계란, 밀가루, 우유 등을 넣고 만들었는데, 그 당시에 비용은 1-3 센트에 불과하였다(평상품). 6-70년대부터 많이 이용되었던 General Mill의 Betty Croker나 Procter \& Gamble의 Duncan Hines(완제 품)는 1-2 달러에 불과 하였으나 그 이전의 평상품에 비하면 업청난 수준이었다. 80 년대에는 슈퍼마켓이나 동네 제과점을 방문하거나 주문을 하여 케이크를 구입하는 수가 많았는데(서비스) 이 매에는 가격이 10-20 달러 정도 하였다. 최근에는 Chuck E. Cheese's, the Discovery Zone, Club Disney 둥 전문 서비스 업체가 인기를 얻고 있는데 이들에게 생일파티를 의뢰한다면(경헙 제공) $100-250$ 달러 정도의 비용이 필요하다.

또한, Pine과 Gilmore는 경혐을 두 가지 차원에 따라 4 가지 유형으로 분류하였다. 첫번찌 차원은 고객의 참여 수준이다. 참여의 적극성에 따라 능동적인 참여와 수동적 참여로 분류하였다. 수동적 참여는 오케스트라 연주회와 같이 관람석에서 조용히 앉아서 참여하는 것이며 적극적 참여는 락 컨서트(rock concert)와 같이 관객도 적극적으로 변하여 환호하고 호웅하는 것이다. 그 다음 차원은 고객과 이벤트/공연과의 연결관계(흑은 환경적 관계)이다. 한가지 유형은 몰두(absorption)로 경험을 자신의 마음속에 가져옴으로써 주의를 기울이는 것이다. 다른 유형은 함입(immersion)으로 신체적으로 혹은 공간적으로 경험 자체의 일부가 되는 것이다. Pine과 Gilmore에 의하면 TV를 열심히 보는 것과 같이 경험이 고객에게 들어가는(input) 것은 몰두라고 할 수 있고 가상현실 게임과 같이 고객이 경험 속으로 들어가게 되면 함입이라고 할 수 있다(이들의 세부적인 주장은 Pine and Gimore 1999를 참조하시오).

또한, Pine과 Gilmore는 경험의 가장 중요한 유형으로 잊지 못할 경험(memorable experience)을 제시하고 있다. 기억에 남을 수 있는 생일 파티, 최고급 패션 브랜드의 착용 경험, 고급 승용차의 위세효과, 적극적인 참여와 함입현상이 일어날 수 있는 오지 탐험 등이 해당된다고 할 수 있다.

\section{4 총체적 경험}

많은 인터넷 사이트들이 방문객들에게 게임이나 다양한 형태의 오락에서 얻을 수 있는 진정한 경험(authentic experience)을 제공하고자 한다(Hurst 1999). 진정한 경혐은 합일감(flow)의 상태일 수도 있고, $\operatorname{Schmitt}(1999,2003)$ 둥이 언급하는 총체적 경험(holistic Experience)일 수 있다. Schmitt(1999)에 의하면 경험은 '자극에 반웅하여 발생한 개인적인 사건(private event that occurs in response to stimulation)'이다. 이 정의는 사전적 정의와 비숫한 것으로 특히 '개인적' 반응을 강조하고 있다. 다음에서는 Schmitt가 언급하고 있는 전략적 경험 단위(strategic experience module, SEM)에 대하여 살펴보기로 하자.

Schmitt는 경험을 감각(sense), 감성(feel), 생각(think), 행동(think), 관계(relate) 등 5 가지 단위로 분류하였다. 먼저, 감각을 전략적으로 활용하기 위해서는 시각, 청각, 촉각, 미각, 후각 등 오감을 적극 활용하여 '감각적 마케팅'을 구사하는 것이 푈요하다. 기능적 제품이라고 할 수 있는 냉장고에 대해서도 감각적 디자인이 중요한 구매결정 요인으로 둥장하였다.Zipel과 Dios는 소비자들이 자신의 취향에 따라 고를 수 있도록 다양한 디자인의 
제품올 선보여 소비자 선택의 폭을 크게 넓혀주고 있다. 감각적 마케팅 방법은 Schmitt와 Simonson(1997)에서 미학적 마케팅이라는 주제로 심충적으로 다루고 있다.

'감성적 마케팅'은 소비자의 정서와 느낌에 호소하는 것으로 온화하고 가벼운 형태의 감성에서 기쁨과 환희, 그리고 자신감 등의 강렬한 감성까지 다양하게 나타날 수 있다. 생각을 유도하는 '이성적 마케팅'은 소비자들이 인지적이고 문제해결적인 경험을 제공하여 소비자롤 유도한다. 또한, 놀람, 호기심, 도발성 둥으로 소비자들이 생각하도록 자극하기도 한다. '행동적 마케팅'은 신체적 경험, 라이프 스타일, 사회적 상호작용 둥에 영향을 미치기 위한 목적으로 수행된다.

'관계 마케팅'은 이상적 자아, 준거집단, 문화 둥을 이용하여 궁극적으로 고객을 브랜드와 연결하고자 한다(Fournier 1998). 할리데이비슨(Harley-Davidson) 오토바이는 야성적이며 도전적인 라이프 스타일을 간명하면서도 효율적으로 제시하고 있다(Oliver 1999). 웹 페이지에서는 피곤한 일상에 젖는 것과 할리데이비슨을 타고 도전적인 삶을 사는 것 중에서 양자택일을 강요하는 과단성을 보이고 있다. 그 결과 이에 호웅하는 애호가들이 브랜드의 문신을 새기기도 하고 자신을 할리데이비슨과 거의 동일시하기도 한다.

Schmitt(1999)는 Volvo C70의 예와 같이 기능적 접근에서 감성적 요소가 추가될 수 있는 것이며, 한 걸음 더 나가서 Singapore Airline과 같이 다섯 가지 형태의 경험적 요소를 모두 제공하는 총체적 경험이 가장 바람직하다고 주장하고 있다.

\section{3. 경험에 관한 네 가지 접근방법의 기여와 문제점 및 한계}

앞에서 살펴본 경험에 관한 네 가지 접근방법의 기여 및 한계를 살펴보기로 한다. 표 2는 전반적인 기여와 한계를 요약하고 있다. 경험에 관한 각각의 접근 방법들은 마케팅 활동에 대한 시각을 넓히고 새로운 마케팅 방식을 제시하는 데에 상당히 기여하였다. 하지만, 관련된 개념들이 아직 명확하게 정리되어 있지 않고 앞으로 추가적인 연구를 통하여 해결해야 하는 문제들이 남아 있다. 또한, 각각의 접근방법은 그 적용범위에 대하여 한계를 가지고 있다. 다음에서는 각 접근방법의 기여, 문제점, 한계에 대한 논의를 수행하기로 한다.

<표 2: 경험에 관한 네 가지 접근 방법들의 기여와 문제점 및 한계>

\begin{tabular}{|c|c|c|}
\hline $\begin{array}{l}\text { 기여와 문제점 } \\
\text { 네 가지 한계 } \\
\text { 접근방법 }\end{array}$ & 각 접근 방법의 기여 & 각 접근 방법의 문제점 및 한계 \\
\hline 정보탐색 관점 & $\begin{array}{l}\text { - 속성에 따라 브랜드 정보를 } \\
\text { 얻을 수 있는 시점에 차이가 } \\
\text { 있다는 점을 강조 } \\
\text { - 소비단계의 중요성을 } \\
\text { 간접적으로 제시 }\end{array}$ & $\begin{array}{l}\text { - 소유권 호과에 의하여 직접적 } \\
\text { 사용 경험에 대한 소유 이후의 } \\
\text { 평가와 시용 시점의 평가에 } \\
\text { 차이가 나타날 수 있음 } \\
\text { - 브랜드의 시용(trial), 가상현실의 } \\
\text { 제공 둥으로 실제 소비경험과 } \\
\text { 유사한 마케팅 방법으로 경험적 } \\
\text { 속성을 탐색적 속성으로 변경할 } \\
\text { 수 있어 속성의 구분이 } \\
\text { 안정적이지 못함. }\end{array}$ \\
\hline
\end{tabular}




\begin{tabular}{|c|c|c|}
\hline $\begin{array}{c}\text { 브랜드 } \\
\text { 컨셉으로서의 경헙 }\end{array}$ & $\begin{array}{l}\text { - 기능적인 컨셉 이외에 상징적, } \\
\text { 경험적 컨셉으로 브랜드를 } \\
\text { 구축할 수 있다는 점을 제시 } \\
\text { - 브랜드 컨셉에 따라 마케팅 } \\
\text { 방식에 차이를 둘 필요가 } \\
\text { 있다는 점올 강조 }\end{array}$ & $\begin{array}{l}\text { - 종종 상징적 컨셉과 경험적 } \\
\text { 컨셉의 구분이 어려움 } \\
\text { - 인지적/감성적, 감각적 요소를 } \\
\text { 복합하여 사용하는 마케팅 } \\
\text { 방법에 대한 평가가 어려움 }\end{array}$ \\
\hline 즐거움의 경헙 & $\begin{array}{l}\text { - 기존의 마케팅 방식과 커다란 } \\
\text { 차이가 있는 즐거움 제공을 } \\
\text { 마케팅의 영역에 도입 } \\
\text { - 즐거움올 결정하는 변수 제시 }\end{array}$ & $\begin{array}{l}\text { - 어떤 조건에서 즐거움 제공이 } \\
\text { 브래h드 구축에 효과적인가를 } \\
\text { 명확히 제시하지 못함 }\end{array}$ \\
\hline 총체적 & $\begin{array}{l}\text { 브랜드 구축을 위한 인지, } \\
\text { 감성, 감각 둥 다양한 방안 } \\
\text { 제시 } \\
\text { 여러 가지 요소의 시너지 } \\
\text { 효과가 나타나는 총체적 } \\
\text { 경험을 강조 }\end{array}$ & $\begin{array}{l}\text { - 각 요소들의 분류가 명확하지 } \\
\text { 않은 것이 많음 } \\
\text { - 여러 요소가 결합할 때에 } \\
\text { 시너지가 나타난다는 주장의 } \\
\text { 근거가 취약함 }\end{array}$ \\
\hline
\end{tabular}

\section{1 정보탐색 관점의 경험}

\section{1 .1 기여}

정보탐색 관점 혹은 정보경제학적인 접근방법의 가장 큰 기여는 일부 유형의 속성, 즉, 경험적 속성이나 신뢰적 속성에 대해서는 직접적 경험이 없이 정보탐색이 가능하지 않다는 점을 명확히 밝힌 것이다(Ford et al. 1990, Nelson 1970). 이들에 의하면 탐색적 속성은 직접적인 브랜드 사용경험이 없어도 광고 둥의 정보에 의하여 큰 무리가 없이 정보를 얻어낼 수 있다. 반면, 경험적 속성 둥에 대해서는 사용 경험이 중요한 정보 역할을 담당하기 때문에 광고 둥과 같은 간접적인 원천으로는 충분한 정보를 얻을 수 없다. 정보탐색적 관점의 연구들에 의하여 경험적 속성에 대해서 소비자들에게 브랜드의 직접적연 경험을 제공할 수 있는 무료샘플, 시식회 둥에 대하여 실무적 관심이 크게 증대하였고 실제로 많은 기업들이 이러한 방식을 활용하고 있다(Hoch 2002, Kempf and Laczniak 2001, Smith and Swinyard 1982, Wright and Lynch 1995).

또한, 정보탐색 관점은 경험적 속성에 대해서는 소비 단계에서 정보를 얼을 수 있다는 점을 강조함으로써 간접적으로 소비단계의 중요성을 제언하고 있다. 사실 고객만족도나 브랜드애호도 등은 대체로 소비 단계에서 구축될 수 있는 것이며(Oliver 1999), 경험적 마케팅이 부각되면서 소비 시점 경험의 중요성이 폭 넓게 받아들여지고 있다(Schmitt 2003). 최근에 많이 수행되고 있는 고객과 브랜드의 관계에 관한 연구들도 소비 단계를 중심으로 관계가 구축되고 있는 점을 강조하고 있다(Fournier 1998, Fournier, Dobscha, and Mick 1998). 실제 소비 행동에서는 브랜드의 구매가 반복적으로 일어나는 경우가 많으며, 이미지도 구매 이전의 광고 둥 마케팅 활동에 한정되지 않고 소비 시점의 직접적인 사용경험을 통하여 형성되는 수가 많다(김완석 1995, Keller 1998, Richins 1997, Schmitt 2003). 


\section{1 .2 문제점 및 한계}

동일한 브랜드에 대해서도 시용 시점과 소비 시점에서 내리는 평가는 달라질 수 있지만, 정보탐색적 관점에서는 짧은 기간의 시용과 구매 후 장기간에 걸친 소비를 구분하지 않는다. 예를 들어 소유권효과(endowment effect)에 의하여 구매 이전에 승용차를 시승하면서 수행하는 브랜드 평가에 비하여 구매 후에 소비 시점에서 내리는 평가가 더욱 높아질 가능성이 있다(Kahneman, Knetsch, and Thaler 1990, Strahilevitz and Loewenstein 1998). 기존 연구들에 의하면 동일한 대상에 대해서라도 소비자들은 소유권을 가진 시점에서 그 이전에 비하여 가치 평가를 높게 하는 것으로 나타났다(Thaler 1999).

또한, 정보탐색적 접근방법으로는 소비경험의 추세에 따라 경험에 대한 평가가 달라지는 현상을 설명하기 어렵다. 브랬드 평가에서 경험의 강도가 긍정적인 방향으로 향상될 때에는 $(1,2,3,4,5$ 의 추세로 경험하는 것이) 같은 수준의 즐거움이 유지되는 것 $(3,3,3,3,3$ 의 추세로 경험하는 것)에 비하여 평균값이 같지만 행복함의 수준이 높아지며, 처음의 소비경험이 낮게 나타난 후에 나아진 경험이 $(1,3,3,3,3)$ 같은 수준의 경혐이 유지되는 경우에 $(3,3,3,3,3)$ 비하여 평균값은 낮은데도 불구하고 개선되는 추세에 의하여 더 높은 수준의 평가를 받을 수 있다(Ariely and Carmon 2000, Kahneman, Fredrickson, Schreiber and Redelmeier 1993).

추가적으로 다음의 상황에서는 정보탐색 관점의 속성 분류를 명확하게 적용하기가 어렵다. 먼저, 상당수의 경험적 속성을 브랜드에 대한 직접 경험을 제공하기 위한 시용(trial)의 형태로 구매 이전의 정보탐색 시점에서 제공할 수 있다(Smith and Swinyard 1982, 1988). 예를 들어 음식을 맛보기로 제공하거나 화장품, 샴푸, 비누 등을 샘플이나 무료 이용 형태로 제공할 수 있다. 이에 대해서는 음악도 마찬가지다. 가수가 마음에 들거나, 혹은 다른 이유로 관심을 가지고 있는 음악을 인터넷을 이용하여 들어 볼 수 있다. Napster나 Gnuttella, 혹은 소리바다 둥의 사이트에서 음악을 다운로드를 받아서 구매 이전에 미리 들어 볼 수 있다. 이러한 방식이 보편화되는 상황에서는 경험적 속성이 자연스레 탐색적 속성으로 변모할 수도 있다(Swinyard and Smith 1988, Wright and Lynch 1995).

인터넷을 이용한 전자 상거래의 발전은 가상현실(virtual reality)을 제공하여 속성간의 구분을 더욱 어렵게 하고 있다(Hoffman and Novak 1996). 예를 들어 책의 내용은 대형서점에서는 이를 읽어 볼 수 있도록 허용하고 있으므로 탐색적 속성에 속한다고 할 수 있다. 하지만, Amazon이나 Barnes\&Noble 등의 인터넷 서점에서는 책의 내용을 전체적으로 홇어 보기가 어렵다. 잘 구성된 책 소개, 목차, 서평, 유명 추천인의 평가, 저자의 견해, 발췌한 일부 내용 등이 이를 대신하고 있지만, 책 내용은 경험적 속성으로 변모하였다. 비슷한 현상은 패션 쇼핑몰에서도 나타난다. 소비자들이 세련된 디자인과 색상의 브랜드를 발견했을 때에 구매하기를 망설이는 것은 실제 눈으로 보는 것과 차이가 날 수 있으며 자신에게 얼마나 어울릴 지에 대해서 확신이 잘 서지 않기 때문이다. 과거에는 탐색적 속성이었던 패션품의 디자인이 경험적 속성으로 바뀐 것이다. 반대로 인기 있는 여행지의 풍경은 과거에는 경험적 속성에 포함되었으나 인터넷에서 볼 수 있는 화질이 좋은 사진을 이용하여 실제로 방문하지 않으면 느낄 수 없었던 분위기의 단먼을 미리 제공할 수 있어 탐색적 속성으로 변화하였다. 


\section{2 브랜드 컨셉으로서의 경험}

\section{2 .1 기여}

Park, Jaworski, Milberg 둥의 연구(1986)는 기능적 컨셉 이외에도 상징적, 경험적 컨셉으로도 브랜드를 구축하고 관리할 수 있다는 점올 부각시켰다. 특히, 연구가 수행된 80 년 중반에는 실무적인 브랜드 구축방법과 학계의 연구방향에는 상당한 간격이 있었다. 실무적으로는 다양한 컨셉을 이용하여 브랜드를 구축하고 있었지만, 학계에서는 정보처리 관점에 치우쳐 상징적, 경험적 컨셉올 구축하는 방안에 대해서는 연구가 거의 수행되지 못하고 있었다(Holbrook and Hirshman 1982).

Park 둥(1986)의 가장 큰 공헌은 컨셉에 따라 도입, 정교화, 강화 단계별로 마케팅 전략의 방향이 달라져야 한다는 점을 명확하게 강조한 것이다. 기능적 컨셉의 브랜드는 정교화 단계부터는 그 기능의 확장을 위하여 노력할 필요가 있는 반면, 상징적 컨셉의 브랜드는 이 단계에서 이미지 보호를 위하여 취급점포를 제한하는 둥 상징성올 보호하기 위한 노력을 강조하였다. 한편, 경험적 컨셉의 브랜드에 대해서는 다양한 유형의 제품을 출시하여 경험 제공 방법올 다양화하는 것이 오히려 최선의 브랜드 구축방안이라고 제안하였다(Park et al. 1996). 이에 비하여 다른 연구들은 단순히 컨셉(흑은 혜택, 접근방법 등)에 대한 분류만을 시도하면서, 경험적 컨셉이 중요한 브랜드에는 경험적 접근을 권하고 기능적 컨셉이 주된 브랜드에는 기능적, 인지적 접근을 권하는 단순한 주장을 제시하고 있다(예를 들어 Holbrook and Hirshman 1982 둥).

\section{2 .2 문제점 및 한계}

브랜드 컨셉 중에서 상징적 컨셉과 경험적 컨셉을 구분하기 어려운 경우가 있다. 프리미엄 패션 브랜드를 과시할 때에 느끼는 위세효과나 젊은 충들이 브랜드를 통하여 자신의 준거집단에 대하여 소속감을 느끼는 것은 소비 경험의 한가지로 상징적 컨셉이 가장 중요하지만, 이 상황에서 여러 가지 유형의 감정올 느낄 수 있기 때문에 경험적 컨셉의 특징올 공유한다. 반대로, 경혐적 컨셉이 중요한 컴퓨터 게임은 동료집단의 사용 여부가 소속감에 큰 영향올 미쳐 상징적인 의미를 갖기도 한다. 실제로 Park, Milberg, Lawson의 연구(1991)에서는 기능적, 상징적 컨셉만올 이용하여 두 가지로 구분하여 연구를 수행하였다. 비숫하게 Aaker, Joachimsthaler(2000)도 가치 제안의 구분으로 기능적, 정서적, 자기표현적인 혜택을 언급하고 있으나 실제 사례에서는 기능적인 것에 대비하여 정서적 흑은 자기표현적 혜택을 묶어서 설명하는 2 분법을 사용하고 있다.

기능적, 상징적, 경험적 컨셉을 명확히 구분하는 포지셔닝 전략이 필요하다는 주장은 감성적, 인지적(혹은 기능적) 반웅올 복합하는 마케팅 활동의 가능성을 배재한다. 브랜드 포지셔넝의 방향을 명확하게 결정하는 것이 대체로 바람직한 것이지만, 일부 상황에서는 경혐적 컨셉과 기능적 컨셉이 상호보완적인 역할을 수행할 수 있다. 에를 들어 기능적인 컨셉의 브랜드인 세제라고 하더라도 빨레 일의 즐거움 등 감성적인 요인을 결합함으로써 더욱 효과적인 브랬드 구축이 가능할 수 있다. 소비자들이 자신이 느끼는 감정적 상태가 의사결정에 적합성이나 적용가능성이 높다고 지각하는 상황에서는 정보처리과정과 결과에 긍정적인 영향을 미치기도 한다(Cacioppo and Gardner 1999, Schwarz and Clore 1996, Zajonc 1998). 


\section{3 즐거움의 경험}

\subsection{1 기여}

즐거움의 경험올 중시하는 관점은 브랜드 구축에 대하여 전통적인 마케팅 방식(Keller 1998, Kotler and Armstong 1996)과는 다른 새로운 방법들을 제시하고 있다는 점에 의의가 있다. 과거의 브랜드 구축방안은 기능적 요소를 지나치게 강조하거나, 인지적 접근방법에 치우쳐 커뮤니케이션 과정에서 자칫하면 소비자들을 지루하게 만들 수 있다(Schmitt 1999). 즐거움의 경험 제공은 브랜드 구축에 놀이의 개념을 도입함으로써 다양한 마케팅 방법을 제시하고 있다(Pine and Gilmore 1998, 1999). 이러한 접근 방법은 실무적으로 큰 호웅을 얻어 광범위하게 적용되고 있는 실정이다.

또한, 이 분야의 연구들은 줄거움을 결정하는 변수를 제시하여 재미나 기쁜 느낌 둥을 창출하는 방안에 대한 이론적 근거를 제시하고 있다. 특히, Csikszentmihalyi(1975, 1990)는 합일감(flow)이 주체인 소비자의 능력과 외부 환경의 도전이 결합하여 두 가지가 모두 높은 수준일 때에 나타난다는 점을 강조하고 있다. 따라서, 노력이 요구되는 즐거움(enjoyment)은 일반적인 즐거움(fun)에 비하여 더 높은 수준의 만족감을 제공할 수 있다고 주장하였다. 이와 비숫하게 Pine과 Gilmore(1999)는 무대 위의 경혐에 큰 의미를 부여면서 최상의 경험으로 보고 있다.

\section{3 .2 문제점 및 한계}

경험에 대하여 즐거움의 요소를 강조하는 연구들은 어떤 조건에서 즐거움의 제시가 브랜드 구축 둥 마케팅 활동에 효과적인가에 대하여 명확한 답변을 내리지 않고 있다. 예를 들어, Pine과 Gilmore는 사회의 발전과정에 따라 경험경제가 도래한다는 주장을 다각도에서 제시하고 있지만 그 적용 범위가 불분명할 뿐만 아니라 경험경제가 도래하더라도 소비자의 욕구는 기능적인 것을 포함하는 다양한 것이 될 것이라는 점을 간과하고 있다. 사회적인 추이에 의하여 즐거움 및 느낌이 브랜드의 구매결정에 점차 중요한 역할을 담당하는 것은 분명하지만 한계조건(boundary conditions)이 무엇인가에 대한 제시가 충분하지 못한 편이다.

Pine과 Gilmore의 모형은 몆 가지 추가적인 한계를 갖고 있다. 먼저, 이들이 제시한 두 가지 차원이 서로 관련성이 높거나 구분이 명확하지 않은 경우가 많고, 몰입의 상황보다는 함입의 경험에서 참여도가 높아지는 문제가 있다. 예를 들어 소비자들이 운동경기를 TV에서 시청할 경우, 경기장에서 관람할 경우, 실제로 경기에 참여할 경우 둥을 비교해보면 몰입의 경험인 $\mathrm{TV}$ 에서는 참여수준이 비교적 낮고 경기장 관람이나 경기 참여 등 함입의 상황에서는 참여수준도 역시 높은 편이다. 이와 같이 두 가지 차원이 상호독립적이지 못한 상황이 많다는 것을 알 수 있다.

Pine과 Gilmore는 잊지 못할 경험을 가장 바람직한 상태로 보고 있으나 이러한 경험이 어떤 변수들에 의하여 형성되고, 또 그 유지 기간이 결정되는가에 대한 답변을 내리지 못하고 있다. 잊지 못할 기억은 이 전에 경험하지 못했던 참신하거나 충격적인 것일 가능성이 높다. 하지만, 비숫한 상황이 반복된다면 이러한 경험도 쉽게 잊혀질 수 있다.

예를 들어 놀이동산 방문경험이 없는 소비자가 에버랜드나 롯데월드률 처음 방문한다면 그야말로 경이적인 눈으로 이를 바라보며 잊지 못할 경험을 얻을 것이다. 하지만, 경험이 축적되면서 그 강렬함은 점차 약해질 수 있다. 비슷하게 생알파티률 쇼와 같이 연출한 경우에도 해마다 반복한다면 경험의 강도는 약해지고, 그 내용을 계속 바꾸어서 
연출하더라도 더 이상 잊지 못할 경험이 아닐 수 있다.

한편, 어떤 상황에서는 시간의 흐름에 따라 오히려 강렬한 경험올 얻기도 한다. 도박이나 컴퓨터 게임올 처음으로 시작하는 사람들은 별다른 재미를 느끼지 못하지만 시간이 지남에 따라 익숙해지고 이에 도전할 수 있는 기술을 습득하여 점차 재미를 느끼면서 더욱 빠져들기도 하며(Csikszentmihalyi 1975, 1990), 경우에 따라서는 중독중의 중세를 보이기도 한다.

\section{4 총체적 경험}

\section{4 .1 기여}

총체적 경험올 강조하는 연구들은(Hurst 1999, Schmitt 1999, 2003) 브랜드구축을 위한 다양한 방법을 제안하고 있다. 예를 들어 Schmitt가 제시한 경험의 전략적 단위는 소비자의 이성에만 국한하지 않고 다양한 요소들을 포함하고 있기 때문에, 차별적인 브랜드 포지셔닝을 위한 프로그램을 유연하게 여러 각도에서 고려하고 결정할 수 있다.

또한, 이러한 접근방법은 정보처리 관점에서 우선시 되었던 기능적, 인지적, 합리적 심리과정이나 속성에 국한 하지 않고 통합적인 게시탈트적인 경험을 강조하고 있다. 소비자들이 실제로 브랜드를 경험할 때에는 기능적 요소에 국한하거나 계산적인 인지과정에만 의존하지 않고 경험적, 상징적, 감성적인 요소들도 적극적으로 고려하고 있다(Hirshman and Holbrook 1982). 이 때에 게시탈트적인 총체적 경험은 감성, 감각, 인지 둥을 포함하면서 상호작용하여 시너지가 나타나는 현상으로 파악할 수 있다.

\section{4 .2 문제점 및 한계}

Schmitt의 모형은 몇 가지 면에서 한계가 있다. 먼저, 감각, 감성, 이성, 행동, 관계 등은 서로 상호작용이 심하여 분리가 어려운 수가 많으며(Cohen and Areni 1991, Schwarz and Clore 1996), 심지어는 구분 조차 명확하지 않은 수도 있다(Zajonc 1998). 예를 들어 Nike의 Just Do It 캠페인은 이성적인가, 행동적인가, 아니면 감성적인가를 판단하는 데에 논란의 여지가 많다. 전략적 경험의 단위(Strategic Experiential Module)가 서로 확연하게 구분되기 어려운 것은 쉅게 구분되는 여러 가지 요소들이 상호작용하여 시너지가 나타나는 것과는 큰 차이가 있다.

추가적으로 여러 요소들을 복합적으로 사용하여 시너지 효과나 총체적 경험(holistic experience)의 효과가 나타나는 조건을 명확하게 제시하지 못하고 있다. 따라서, 전략적 경험 단위들올 통일성올 가지고 이를 관리할 필요가 있는 것인지, 아니면 각각을 독립적으로 관리하여도 무방한 것인지를 정확하게 언급하고 있지 않다. Schmitt(1998)가 예로 들고 있는 Volvo C70이나 Singapore Airline 사례에서는 전략적 경험 단위들이 서로 독립적인 것으로 단순히 복합한 것으로 서로 유기적으로 연결되어 통일성을 가지고 있는 것이 아니라고 판단된다.

\section{4. 경험에 관한 종합적 논의}

마케팅에서 사용하고 있는 경험의 의미는 대개 두 가지 유형으로 분류할 수 있다. 먼저, 
경험은 소비자가 브랜드를 직접 사용하는 것을 의미하기도 하며, 이 때에는 주로 구매 후 소비 활동과 관런이 있다. 직접적인 사용 경험은 구매 이후에 주로 나타나지만, 부료 샘플 제공 등의 마케텅 활용에 의하여 구매 이전 단계에 나타나기도 한다. 이러한 접근 방법을 채용하고 있는 대표적인 연구들로는 Ford 등(1990), Hoch (2002), Schmitt (1998), Smith와 Swinyard (1988), Wright와 Lynch (1995), Schmitt (1999) 둥이 있다.

또한, 경험은 감성적, 감각적, 캐락적, 상징적 요소가 강한 것을 뜻하기도 하며 인지적, 합리적 요소에 대비되는 의미를 갖고 있기도 하다. 학자에 따라 2분법(Park, Milber, and Lawson 1991, Shiv and Fedorikhin 1999) 혹은 3분법(Aaker 1996, Keller 1993, Park, Jaworski, and MacInnis 1986)을 사용하고 있지만 대체로 경험을 감성적 요소와 관련성이 깊은 것으로 보고 있다. 다음에서는 마케팅에서 활용하고 있는 경험의 두 가지 유형, 즉, 소비경험(혹은 직접 경험)과 감성적 경험에 대하여 논의하기로 한다.

\section{1 소비 경험}

\section{1 .1 소비 경험의 특징}

소비 경험은 보통 브랜드의 직접적인 사용 상황에서 나타나는 접촉을 의미하기 때문에 다음과 같은 특징을 가지고 있다.

첫째, 감정적 요인이 중요한 역할을 담당한다. 실제로 많은 학자들이 브랜드 애호도를 결정하는 데에 중요한 역할을 담당하는 소비 경험에는 인지적 요소도 포함되어 있지만 감성적 요소를 포함하고 있다는 견해를 가지고 있다(Blackston 1992, Chaudhuri and Holbrook 2001, Gruen, Summer, and Acito 2000, Pritchard, Havitz and howard 1999). Fournier, Dobscha, Mick 등(1998)은 브랜드 애호도를 단순히 반복구매로 취급하고 있는 문제점을 극복하기 위하여 감성적 요인을 포함한 '고객과 브랜드와의 관계구축'에 관한 이론적 틀을 제안하였다. 소비 단계에서 중요한 변수로 취급하고 있는 고객만족, 신뢰 등은 인지적인 특성이 강하지만 몰입, 애호도, 감성적 애착, 관계의 질 등은 감성적 요인이 중요한 요소가 된다. 더구나, 고객만족이나 신뢰 둥 인지적 특성이 강한 변수들 조차 높은 수준에 도달하기 위해서는 감성적 요인이 가미될 필요가 있다(Oliver 1999).

또한, 구매 이전 단계에서는 브랜드에 대하여 지불하는 가격과 소비 단계의 효용 혹은 즐기움올 비교하기 때문에 감성적 특성이 강한 브랜드에 대해서도 목적 지향적이고 합리적인 특성이 강한 의사결정이 수행될 수 있다. 이에 비하여 소비 단계에서는 거래 지향적이고 계산적인 의미가 크게 줄어들고 소비자돌이 상징적, 캐락적, 미적 요소를 중시하면서 소비 자체의 재미와 흥미 둥에 더욱 관심을 갖게 된다(Holbrook and Hirshman 1982).

둘째, 직접 사용에 의하여 형성된 브랜드 이미지는 명료성(vividness)이 높을 가능성이 크다(Hoch 2002, Smith and Swinyard 1983). 고화질의 TV, 인터넷, 사진 둥에 의하여 현실 세계의 브랜드와 미디어에서 간접적으로 전달하는 브랜드 이미지와의 차이가 크게 좁혀지고 있으나, 아직은 입체적인 느낌을 주는 데에 한계가 있으며 이미지의 명료성에도 열등한 편이다. 또한, 브랜드를 미디어상에서 시각과 청각에 의존하여 구현할 수 있지만, 후각, 촉각, 미각 등을 자극하는 데에는 어려움이 크다.

셋째, 사회적 요인이 브랜드 구축에 중요한 의미가 있다. 예를 들어 브랜드의 상장성은 소비 단계에서 가장 잘 구현될 수 있는데 다른 사람들과의 관계에서 더욱 영향력을 
발휘한다. 자신이 사용하는 브랜드률 타인에게 과시하거나(Park, Jaworski, and MacInnis 1986) 아니면 브랜드 커뮤니티와 같이 브랜드률 매개로 동류 집단에 소속감올 느끼는 것(McAlexander, Schouten, and Koenig 2002, Munitz and O'Guinn 2000)은 모두 사희적 상황에서 의미가 있다. 구매 이전에도 다른 사람의 브랜드를 부러워하거나 구전효과에 의하여 영향올 받는 둥 사회적 요인이 브랜드 이미지 구축 및 구매결정에 중요한 영향 요인이 되지만, 구매 이후의 소비 경험에서는 사희적 요인이 한충 더 중요한 역할을 담당한다(Herr, Kardes, and $\operatorname{Kim} 1991$ ).

\section{1 .2 소비 경험과 다른 변수들의 관계}

브랜드에 대한 소비경험은 고객만족, 브랜드 애호도, 몰입, 신뢰, 감성적 애착, 관계의 질, 브랜드 이미지 둥과 관련이 깊으며, 소유권 효과에 의하여 영향올 받기도 한다. 다음에서는 소비 경혐과 이돌 변수들과의 관계률 살펴보기로 한다.

첫째, 고객만족, 브랜드 애호도, 몰입, 신뢰, 감성적 애착, 관계의 질 등의 변수는 소비 경험(흑은 사용 경험)을 전제로 한다. 신뢰와 감성적 애착은 아직 체계적인 연구가 많이 수행되어 못한 편이지만 소비 경험 이전에는 잘 형성되지 않기 때문에 소비 경험에 의한 이미지를 구매 이전 단계의 이미지와는 명확히 구별할 수 있는 변수들이다. 이들은 비교적 단순하고 측정도 용이한 편으로 실무적 활용도가 높으며 학계에서도 많은 연구가 수행될 필요가 있다. 소비 단계에서 가장 많이 사용하는 변수는 고객만족이지만, 지나치게 이성적, 인지적 관점을 가지고 있으며 장기적 관계 지향성 보다는 단기적 거래 위주로 현상을 파악하였다는 비판을 받은 바 있다(구체적인 논의는 Oliver 1999와 Fournier 와 Mick 1999를 참조하시오). 한편, 브랜드 애호도와 몰입은 아직 명확한 개념 정립이 되어 있지 못하며(Fournier 1998), 관계의 질은 지나치게 복잡하다는 문제가 있다.

둘째, 소비 경험은 브랜드 이미지에 상당한 영향을 미친다. $\operatorname{Keller(2003)ㅇㅔ~ㅇㅢㅎㅏㅁㅕㄴ~ㅅㅗㅂㅣ~}$ 경험은 브랜드 선택에 영향을 미치는 가장 중요한 요인이다. 이는 브랜드 이미지 혹은 연상(image or association)이 강하기 때문이다. 또한, 위에 언급한 바와 같이 소비 경험 후의 브랜드 이미지는 소비 경험 이전에는 관련되기 어려운 신뢰, 감성적 애착 둥의 변수에 의하여 영향을 받기 때문에 구매 이전의 이미지나 연상과는 상당한 차이가 날 수 있다.

셋째, 소비경험에는 소유권 효과가 포함되어 평가에 영향을 미칠 수 있다. 동일한 제품을 소유하였을 때와 그렇지 않올 경우 선택(포기하는 것과 새로이 혁득하는 것)에서 상당한 차이가 나타나며 이러한 현상은 다양한 상황에서 관찰되고 있다(Thaler 1999). 소유권 효과의 원인에 대해서는 소유물을 소비자 자아의 확대로 보고 애착에 의하여 실제적인 평가가 높아진다는 견해(Beggan 1992)와 소유물에 대한 평가는 변동하지 않지만 단지 손실(포기)을 이득(획득) 보다 크게 받아들이기 때문에 선택에만 영향올 미친다는 견해(Thaler 1999)가 있다.

\section{2 감성적 경험}

\section{2 .1 감성과 이성의 구분}

직관적으로는 감성과 이성이 섭게 구분되는 것 같이 보이고 감성과 이성은 차이가 있는 것은 분명하지만, 때로는 그 구분이 명확하지 않으며 심하게 상호작용하기도 한다(Zajonc 1998). Schwarz와 Clore (1996)에 의하면 감성은 기억이나 학습 둥 인지적 과정에 영향을 
미치고, 감성적 반웅 자체가 정보로 활용되기도 하고, 감성이 자동적인 신체반웅에 영향을 미치기도 한다.

감성적 경험은 기억의 연상네트워크에 영향을 미쳐 학습과 기억에서 중요한 역할을 담당할 수 있다(Bower 1981). 상태 종속적 학습(state dependency learning)에 의한 기억 모형(Bower 1981)에 의하면 부정적(혹은 긍정적) 감성의 상태에서 학습한 내용은 동일한 감성 상태에서 더욱 기억할 가능성이 높다. 예를 들어 기분이 좋은 상태에서 브랜드에 대한 광고를 보았다면 유사한 감성적 상태에서 이를 기억할 가능성이 높다는 주장이다. 이러한 현상은 톡히 긍정적 감성의 유형에서 잘 나타난다. Wyer, Clore, and Isbell(1999)는 이러한 현상에 대하여 기억의 가능성을 높여주는 것은 감성적 상태가 일치하기 때문이 아니라 관런된 생각이 유사하여 매개변수 역할을 수행하기 때문에 나타나는 현상이라고 인지적 관점에서 재해석하였다.

한편, 태도에 관한 연구들은 인지가 감성에 영향올 미친다는 견해를 가지고 있다. 브랜드의 속성에 대한 신념(belief)과 중요도(importance)가 인지적 과정을 거쳐 호의적, 비호의적인 감성(태도)을 형성한다는 가정을 근간으로 하고 있으며, 특히 인지적 과정에서 유발되는 생각들의 방향이 결국 태도의 호의성, 비호의성을 결정한다는 모형에 의존하고 있다( Petty and Cacioppo 1981).

\section{2 .2 감성적 반웅의 유형}

감성적 반웅을 분류하는 방법은 대단히 많지만(예를 들어 소비경험을 행복, 즐거움, 환희 등 반응의 특성에 따라 다양한 유형으로 분류한 이학식, 임지훈 2002, Richins 1997, 감성의 대상이 명확한가와 방향성에 따라 무드, 감정(emotion), 감성(affect)으로 분류한 Wyer, Clore, Isbell 등과 같은 분류) 본 연구에서는 감성적 반응의 형성 방법에 따라서 유형을 분류하고자 한다.

감성적 반응은 형성방법에 따라서 초콜릿 케이크를 보고 먹고 싶다는 생각이 드는 것과 같이 '자동적인 반웅(automatic response)'과 이러한 반웅과 영양과 살찔 가능성 등의 인지적 정보를 종합적으로 생각함으로써 '인지적 통제과정을 거친 후에 나타나는 반웅(controlled response)'으로 구분할 수 있다(Berkowitz 1993, Shiv and Fedorkhin 1999). 자동적 반웅은 즉각적이고 인지적 과정에 크게 의존하지 않지만, 인지적 톻제과정 후에 나타나는 감성적 반웅은 여러 가지 요인을 함께 고려하기 때문에 상대적으로 반웅이 늦은 편이다.

Wyer, Clore,Isbell 등(1999)은 이러한 두 가지 유형을 감성 기반 평가(affect-based evaluation)와 설명 기반 평가(descriptively based evaluation)로 나누고 있다. 치과에 가는 것은 감성 기반 평가에서는 부정적인 것이지만 치아건강이라는 목적을 달성하기 위한 설명 기반 평가에서는 긍정적이다. 맛있는 스낵을 먹는 것은 두 가지 평가에서 그 방향성이 반대의 결과가 나타난다. 이와 유사하게 Schwarz와 Clore (1983)은 사람들은 본인의 행복에 대한 평가를 수행할 때에 날씨에 의하여 기분이 좋은 상태라는 감성적 정보가 적합성이 떨어진다고 느끼고 자신이 감성적 상태(날씨에 의하여 기분이 좋음)에 의하여 영향을 받는다고 느낄 때에는 귀인의 과정을 거쳐서 의사결정 결과에 대한 감성의 역할을 스스로 통제한다는 뗜구결과를 발표하였다.

Pham, Cohen, Pracejus, Hughes 등(2001)은 이러한 연구들을 토대로 35개의 잡지 사진을 이용하여 '자동적인 감성반웅'이 인지적 통제반웅에 비하여 속도가 빠르고, 개인들간에 차이가 적으며, 관련된 생각들의 방향성(부정적, 긍정적)이 일관성이 높다는 결과를 얻었다. 
즉각적인 감성 반응의 조건에서는 전반적인 감정적 즐거움(the overall pleasantness of your feeling), 그리고 이성 기반의 평가 조건에서는 전반적인 평가(the overall evaluation)에 대하여 답하도록 하였다. Pham 둥의 연구는 깔끔한 실험과정을 통하여 인지적 반웅과 감성적 반웅이 서로 다른 소비자 반웅을 얻올 수 있다는 것올 명확히 보여 주는 반면, 결과를 '지나치게 일반화하여 해석하는 문제'가 있다.

먼저, Pham 둥은 정보처리 목적에 따라 유용한 정보가 달라질 수 있다는 기존 연구들의 주장을 간과한 것으로 보인다. 반웅 속도와 개인적 차이에 대해서는 논란의 여지가 없지만 정보처리 과정에서 관련된 생각이 일관성이 높기 때문에 인지적, 기능적 접근방법에 비하여 마케팅활동의 효율올 높인다는 주장은 실중분석 결과를 지나치게 일반화한 것으로 평가할 수 있다. 마치 벤츠에 대한 감성적 반응(전반적인 감성적 즐거움)이 가격, 디자인, 성능 둥 벤츠와 관련된 여러 정보를 포함하는 브랜드에 대한 평가(전반적인 이성적 평가) 보다 일관성 있는 정보처리가 가능하기 때문에 다른 요인들을 무시하고 감성적 즐거움을 마케팅 활동의 핵심으로 삼아야 한다는 논리와 유사하다.

또한, 감성적 반웅이 인지적 평가에 비하여 전반적인 브랜드평가에 중심적 역할을 담당하고 있는다는 강력한 근거로 제시한 STUDY2(Pham et al. 2001)의 결과에 대한 해석 역시 지나치게 일반화한 주장으로 보인다. Pham 둥은 회귀분석 결과 인지적 평가(독립변수)에 비하여 감성적 반웅(독립변수)이 생각의 방향성(긍정적, 부정적, 종속변수)과 휠씬 일치한다는 결과를 얻었고 이를 근거로 감성적 반웅이 먼저 일어나면서 인지적 평가에 비하여 최종적인 평가에 횔씬 큰 영향을 미친다고 주장하였다. 이러한 주장은 감성적 반응은 즉각적으로 나타나는 자동적인 반응과 인지적 과정을 거친 후에 나타나는 반응으로 나눌 수 있다는 점을 간과한 것이다. 이들이 분류한 감성적 반웅은 두 가지 유형을 모두 포함한 것으로 보이며 특히 인지적 과정을 거친 후에 나타나는 감성적 반응이 섞여 있는 것으로 보인다. 인지적 평가와 평가 결과로 즉시 나타나는 감성적 반응을 명확히 구분하기는 대단히 힘들다. '인지적 평가'가 소비자들의 반웅으로 나타나는 '생각의 방향성’과 상관관계가 높게 나타나는 것이 일반적이지만(Pham et al. 2001), 분석결과에는 상관관계가 거의 없는 것으로 나타났다. 그들의 연구결과에 따라 '자동적 감성 반응'이 '생각의 방향성'에 영향을 미치고 이에 따라서 전반적인 브랜드 평가에 영향을 미친다는 것은 비교적 명확한 해석이지만, '자동적 감성 반웅'이 '인지적 평가'에 비하여 브랜드의 평가에 상대적 영향력이 높다는 주장은 다소 무리가 있는 것으로 보인다.

\section{2 .3 감성이 정보처리과정과 평가결과에 미치는 영향}

정보처리과정과 의사결정결과에 대한 감성의 영향력은 조건에 따라 큰 차이가 있다. 특정한 조건에서는 감성이 소비자들이 브랜드롤 평가하는 과정 및 결과에 큰 영향을 미치지만, 언제나 영향력을 발휘하는 것은 아니다(Wyer, Clore, and Isbelle 1999). 감성의 영향력은 소비자의 의사결정 목적(decision goals), 적용가능성(applicability), 귀인과정(attribution processes), 인지적 자원(cognitive resources), 정보처리방식의 선택 (choice of an information process strategy) 둥에 의하여 조절된다. 다음에서는 각각의 변수에 대하여 감성이 정보처리과정 및 의사결정 결과에 영향을 미치는 조건을 살펴보기로 한다. 다음의 그림은 각 변수들이 미치는 영향올 정리한 것이다. 
<그림: 감성적 반웅이 의사결정과정과 결과에 미치는 영향>

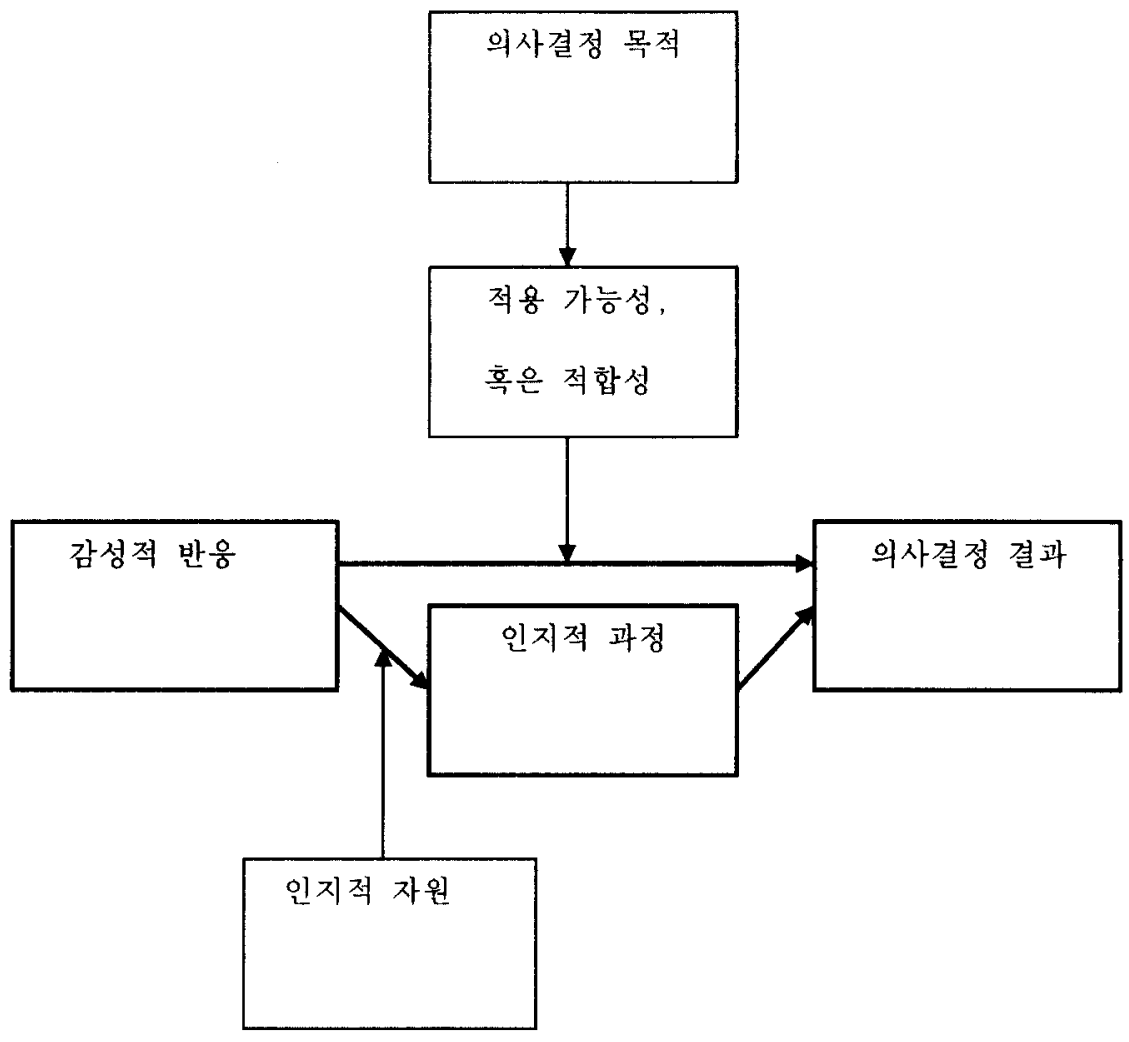

- 인지적 과정에서 여러 가지 정보가 투입변수로 같이 활용될 수 있으나 모형의 단순화를 위하여 감성적 반웅 이외의 투입변수는 생략하였음.

1) 의사결정 목적

의사결정 목적은 순수하게 인지적인 정보처리과정 뿐만 아니라 감성적 정보의 영향력예도 중요한 역할울 담당한다(Gollwitzer and Moskowitz 1996). Schwarz와 Clore(1996)에 의하면 사람들은 종종 “내가 그 것에 대하여 어떻게 느끼고 있는가(How do feel about it?)"를 평가를 결정하는 정보로 사용하기도 한다. 이러한 현상은 음식의 맛이 좋은가, 혹은 이 사람을 좋아하는 둥의 평가와 같이 7 자체가 감성적인 톡성과 목적을 가지고 있는 상황에서 나타난다. 비슷하게 Wyer 둥(1999)도 의사결정목적이 평가 과정 및 결과에 지대한 영향을 미친다고 주장하였으며 감성이 결정적인 역할을 담당하는 감성기반 평가는 의사결정 목적이 감성적인 성향을 갖을 때에 나타난다고 주장하였다. 이러한 상황은 인생에 대한 전반적인 만족감, 자존심에 대한 느낌, 사랑의 느낌 둥을 평가하는 조건 둥이 포함된다.

Pham(1998)은 Schwarz와 Clore의 이론을 사용하여 소비자의 동기(의사결정 목적)에 따라 무드가 정보로 사용되어 특정 대상에 대한 평가에 영향을 미치는 정도가 달라질 것인가를 살펴보았다. 그 자체가 목적이 되는 완성형 동기(consummatory motive) 조건(영화를 보고 즐기는 것이 목적)에서는 피험자들이 실험적으로 유발된 감성적 상태(무드)에 의하여 평가에 
영향올 받았지만, 수단적 동기(instrument motive) 조건(영화를 대가를 받고 평가하는 상황)에서는 무드에 의한 영향력이 사라졌다.

한편, 충동구매와 같은 상황에서는 감성적 자극이 의사결정 목적에 영향을 미칠 가능성이 높다. 감성적 반웅이 종합적인 정보처리과정의 결과로 나타나는 평가에 비하여 빠르게 나타난다. 앞에서 언급한 바와 같이 자동적 과정에 의한 감성적 반응은 인지적 통제과정을 거친 감성적 반웅에 비하여 그 속도가 빠르기 때문에 선행적으로 나타날 수 있다(Pham et al. 2001, Wyer et al. 1999). 따라서, 정보처리 목표가 불확실한 상황이나 브랜드(자극)의 감성적 강도가 강할 경우에 인지적 통제과정을 거치지 않거나 이에 대한 영향을 적게 받을 수 있다. 예률 돌어 소비자들은 막연히 갠찮은 오디오률 구매하려고 여러 점포를 방문하다가 우연히 마음에 꼭 드는 멋진 디자인의 브랜드를 발견하고는 무리한 수준의 금액을 지불하고 이를 구매하기도 한다.

2) 감성적 정보의 적용가능성 혹은 적합성

의사결정과정에서 특정 정보의 사용 여부는 일반적으로 기억의 인출가능성과 적용가능성(accessibility and applicability)에 의하여 결정된다(Higgins 1996). 즉, 기억이 용이할수록, 그리고 적용가능성이 높다고 평가할수록 정보의 활용 정도가 높아질 것이다. Feldman과 Lynch(1988)도 이와 유사하게 기억의 접근가능성과 진단성(diagnosticity)을 정보 활용 수준의 중요한 결정 요소로 제시하였으며, 이들의 이론은 마케팅 분야의 연구에서 널리 활용되고 있다.

Schwarz와 Clore (1983, 1996), Wyer, Clore, Isbell (1999)에 의하면 감성적 정보는 적합성(relevance), 혹은 적용가능성이 높을 경우에 활용된다. 물론 이 때 감성적 정보의 적합성은 의사결정 목표와 관련이 높은가에 달려 있다. 이들의 연구는 감성적 정보가 조건 없이 보편적으로 활용되는 것이 아니라 적합성이 높은 수준에만 활용할 수 있다는 것올 보여주고 있다.

예를 들어 음식의 맛을 평가할 때에는 과거 음식을 맛본 경험에 의존하는 것이 성분을 분석하여 맛을 추론하는 인지적인 과정을 거치는 것에 비하여 적합성이 횔씬 높기 때문에 활용된다. 하지만, 막상 건강까지 고려하여 음식을 주문할 것인가를 결정하는 상황에서는 맛뿐만 아니라 다른 기능적 요인들올 인지적으로 고려한 후에 결론을 도출한다. 건강을 대단히 중시하는 소비자들에게는 맛에 대한 감각적, 감성적 정보가 거의 무시될 가능성도 있다.

\section{3) 귀인과정}

소비자들은 브랜드와 관련된 감성적 정보에 의하여 자신의 판단이 영향을 받고 있다는 것을 지각하고 있으며 동시에 의사결정 목표에 비추어 적합성이 적다고 믿을 때에는 귀인과정(attribution process)을 거쳐 그 영향력을 감소하려고 한다(Schwarz and Clore 1996). 사람들은 좋은 날씨에 의하여 유발된 긍정적 무드에 의하여 영향올 받올 때에 그렇지 않은 상황에 비하여 자신들의 삶을 더욱 행복하다고 평가한다. 하지만, 이러한 현상은 날씨에 주목하지 않아 귀인현상이 나타나지 않는 조건에 한정된다. 날씨에 주목하게 되면 자신들이 평가과정에서 무드에 의하여 영향을 받았다고 귀인하기 때문에, 무드에 의한 영향을 감소하기 위하여 평가를 하향 조정하는 경향이 있다(Schwarz and Clore 1983).

이 때에 사람들은 자신들이 무드에 의하여 정확하게 어느 정도 영향을 받고 있는지를 
파악하지 못하는 것 같다. Schwarz와 Clore(1983)는 실제로는 무드애 영향을 미치지 못하는 것으로 알려진 실험실 상황에 주목하여 귀인을 유도하는 조건과 통제조건을 비교하였다. 무드에 영향올 미치는 못하는 실험실 상황에 주목을 하더라도 피험자들은 잘 못된 귀인 과정(misattribution process)을 거친다. 따라서, 자신들의 삶에 대한 평가를 하향 조정하여 통제조건의 피험자들과 평가에서 차이가 나타났다. 만약에 사람들이 실험실 상황에서 영향을 받은 정도를 정확히 귀인할 수 있었다면 실험조건과 통제조건에서 행복감에 대한 평가는 동일한 수준으로 나타났을 것이다.

4) 인지적 자원

Shiv와 Fedorkhin(1999)는 인지적 자원을 통제함으로써 동일한 대안들에 대한 선택 확률을 조절할 수 있다는 연구결과를 얻었다. Berkowitz(1993)과 Wyer 등(1999)에 의하면 즉각적인 감성적 반응은 전반적인 정보처리과정(흑은 인지적 통제과정) 후에 생성되는 평가적 반웅에 앞선다. 따라서, Shiv와 Fedorkhin은 인지적 자원 수준이 높은 상황에서는 통제과정을 거칠 가능성이 높기 때문에 상대적으로 즉각적인 감성적 반응이 평가에 영향을 적게 미칠 것이지만 인지적 자원 수준이 낮은 상황에서는 통제과정을 거치지 않기 때문에 감성적 반응이 영향을 크게 미칠 것이라고 추론하였다.

이들은 일곱 자리 숫자를 기억해야 하는 인지적 자원이 적은 조건과 이러한 과업이 주어지지 않아 인지적 자원이 많은 조건에서 각각 초콜릿 케이크와 과일 샐러드 중에서 선택을 하도록 하였다. 인지적 자원이 적은 상황에서는 통제과정을 거치기 어려워 감성적 반웅이 평가에 중요한 역할을 담당하여 초콜릿 케이크를 더욱 많이 선택하였다. 하지만, 인지적 자원이 풍부한 상황에서는 통제과정을 거칠 가능성이 높기 때문에 과일 샐러드를 선택한 피험자들의 수가 많았다.

Shiv와 Fedorkhin의 연구는 의사결정 목표가 명확하지 않고 감성적 정보의 적용 가능성이나 적합성을 평가하기 어려운 상황에서는 인지적 자원이 충분하여 “인지적 과정을 잘 활용할 수 있는가"에 따라 다른 선택 결과가 나타날 수 있다는 사실을 보여주고 있다. 따라서, 이들의 연구에서 의사결정 목표와 감성적 정보의 적합성 여부를 비교적 명확하게 판단할 수 있는 상황이 제시되었다면 동일한 결과를 얻기 어려웠을 것이다.

5) 정보처리방식의 선택

소비자들의 무드는 정보처리방식에도 영향을 미친다(Schwarz and Bless 1991). 긍정적인 무드 상태에서는 현재 상태를 그대로 유지하고자 하는 동기가 작용하여 새로운 정보를 치밀하게 처리하고자 하지 않으며 분석적이지 못하여 포괄적이고 정보처리를 수행할 가능성이 낮지만, 부정적인 측면보다는 긍정적인 측면을 바라보기 때문에 새로운 아이디어를 쉽게 수용할 가능성이 높으며 창의적인 아이디어를 내기가 용이하다(Schwarz and Clore 1996). 부정적인 무드 상태에서는 현실에 대한 통제력을 확보하기 위한 동기가 높아져서 정보를 분석적으로 파악한다. 따라서, 부정적인 무드 상태에서는 통제력 확보를 위하여 높은 수준의 정보처리를 수행할 가능성이 높으며(Wyer et al. 1999), 다양성 추구 성향이 높아지기도 한다(양윤, 최훈회 2002).

한편, Wegener, Petty, Smith 등(1995)은 무드에 의한 영향이 정보의 방향성(valence)에 의하여 조절된다는 점을 밝혔다. 부정적인 무드가 긍정적인 무드에 비하여 상대적으로 정보처리 수준을 높여준다는 일반적인 원칙이 부정적인 정보가 제공될 때에는 그대로 
적용되지만, 긍정적인 정보가 제공될 때에는 긍정적인 무드에서도 동일하게 정보처리 수준이 높아지는 실중결과를 얻었다.

\section{5. 경험에 관한 연구들의 실무적 시사점}

여러 경헙적 접근방법들은 브랜드 구축에 대하여 다양한 아이디어를 제공할 수 있다는 장점이 있으며, 이러한 경험적 특성올 인지도나 이미지 등 지식구조로 모두 설명하기는 어렵다. Keller(1993, 1998)가 기억의 네트워크 구조에 의존하여(Loftus and Loftus 1980) 주장한 바와 같이, 경험올 이미지의 호감도(favorability), 독특함(uniqueness), 강력함(strength) 둥에 영향을 미치는 요소로 볼 수도 있다. 하지만, 인지도나 이미지는 마케텅 활동의 결과로 나타나는 것이기 때문에 브랜드 구축 정도롤 사후적으로 평가하기에는 유용하지만, 브랜드를 구축하는 구체적인 방법을 사전적으로 제시하기는 어렵다. 경험에 관한 연구들의 다양한 관점은 구체적이고 새로운 마케팅 프로그램을 제시하는 데에 좋은 대안들이 될 수 있다. 다음에서 각각의 접근방법이 제시하는 실무적인 시사점을 살펴보기로 한다.

\section{1 네 가지 경험적 접근 방법들의 시사점}

첫째, 정보경제학 흑은 정보탐색 관점의 연구에서는 브랜드가 강조하는 속성이 탐색적, 경험적, 신뢰적인가에 따라 마케팅 방식에 차이를 두는 것을 권하고 있으며(Ford, Smith and Swasy 1990) 이를 마케팅 커뮤니케이션의 선택에 기준으로 삼을 수 있다. 탐색적 속성은 광고 둥의 정보에 의해서도 충분히 브랜드를 평가할 수 있지만 음식의 맛 등 경험적 특성은 직접적인 브랜드 사용이 가장 확실한 정보원이 되기 때문에(Smith and Swinyard 1982, 1988, Wright and Lynch 1995) 무료 샘폴이나 시음회, 시식회 등이 중요한 마케팅 수단이 될 수 있다.

둘째, 브랜드 컨셉 및 이미지에 관한 연구(Park, Jaworski, and McInnis 1986)는 컨셉의 차이와 브랜드 구축 단계에 따라 마케팅 전략이 달라질 수 있다는 점을 제시하였다. 고가 패션품과 같이 상징적 컨셉을 가진 브랜드에 대하여 시장보호 전략을 통하여 판매량, 매장의 수를 한정하여 브랜드 이미지 등을 강력하게 유지할 필요가 있다. 또한, 경험적 컨셉의 브랜드에 대해서 다양한 경험 창출을 위하여 제시한 관런 제품의 엑서서리전략은 엔터테인먼트 산업의 성공적인 수읙 모델과도 일치한다.

셋째, Pine과 Gilmore의 연구를 활용하여 이벤트 프로그램에서 고객의 참여를 유도하여 프로그램의 효율성을 높일 수 있다. Pine과 Gilmore는 단순히 엔터테인먼트와 경험을 동일시하지 않고 고객의 참여 정도와 함입/몰입의 차원으로 분류하여 적극적이고 함입의 단계에서 가장 풍부하고 영향력 있는 경험이 나타날 수 있다는 점을 강조하고 있다. 이들의 연구는 엔터태인먼트 산업에서 실무적으로 사용해왔던 기법들을 잘 정리했다는 점에 의의가 있다. 비숫하게 마케팅 프로그램을 운영할 때에 기존 열성 고객의 참여와 함입을 유도하여 강력한 관계구축의 수단으로 삼을 수 있다.

넷째, 경험적 마케팅을 위한 Schmitt의 전략적 마케팅 단위들은 브랜드 구축을 위한 다양한 방법을 제시하고 있으며 마케팅 프로그램의 방향 결정에 유용한 지침을 제공하고 
있다. 특히, 감각적 마케팅 기법들은 많은 기업들이 로고나 패키지 둥의 디자인에 상당한 노력을 기울이고 있는 현상과 잘 부합하는 방식이다(Henderson and Cote 1998, Veryzer and Hutchinson 1998). 스타일이 세련되거나 호소력 있는 주제를 자신만의 형식을 창출하여 감각적인 즐거움을 제공하는 방식은 경험적 마케팅에서 크게 주목을 받을 수 있는 주제가 될 수 있을 것이다.

\section{2 감성적 경험과 총체적 경험의 효과}

\section{2 .1 감성적 경험의 효과}

우리는 종종 감성의 시대에 살고 있다는 표현을 듣는다. 코카콜라의 "생각을 멈추고 느껴봐(Stop thinking. Feel it)" 광고가 이러한 추세률 잘 대변하고 있다. 다음의 이유로 앞으로 마케팅 프로그램을 수행할 때에 감성적 경험을 적극 활용할 필요가 있다.

먼저, 전반적으로 사회가 풍요로워지면서 느낌을 중시하는 경향이 더욱 심화되고 있다. 젊은 충의 은어인 “필이 꽂히다(줗은 느낌이 든다)"에서 이러한 추세를 읽올 수 있다. 동일한 제품에 대해서도 감각이나 감성적 호소가 중요해지는 성향이 나타나고 있다. 냉장고나 청소기와 같이 기능적인 제품에 대하여 과거에는 브랜드에 대한 이성적, 인지적 호소가 효율적이라고 믿어왔으나 최근에는 디자인이나 감성에 호소하는 브랜드가 부쩍 늘어나고 있다.

그 다음으로는 여태까지 실무나 학계에서 브랜드의 기능적 특성이나 소비자의 인지적 관점이 지나치게 강조하였기 때문에 감성적, 감각적 접근방법은 적절한 수준 이하로 활용되었다고 할 수 있다. 아직은 많은 기업들이 감성적 호소에 크게 의존하지 않고 있기 때문에 다양하고 새로운 접근이 가능할 뿐만 아니라 감성적인 표현방식을 사용하여 자연스럽게 차별화 효과를 얻을 수 있다.

하지만, 감성적 접근이 보편적으로 효과적인 것은 아니며, 이성적, 기능적 방식을 강조하는 기존의 마케팅 접근방법을 전적으로 대체하는 것은 아니다.

먼저, 감성의 경우에도 의사결정 목적과 감성적 반웅이 적합한 것인가 하는 판단 등에 의하여 그 효과가 조절되기 때문이다. 소비자들은 필요하다면 언제나 인지적인 통제과정을 거칠 것이기 때문에 감성적 반응이 평가나 구매결정에 '적용가능성(applicability)'이나 '적합성(relevance)'이 높은 상황에서만 효과를 발휘할 수 있다(Schwarz and Clore 1996, Wyer et al. 1999). 인지적 자원이 풍부하거나 비만을 걱정하는 소비자들에게는 초콜릿 케이크의 매력(맛)에 의한 영향력이 인지적 통제과정에 의하여 크게 감소할 수 있다(Shiv and Fedorkhin 1999).

둘째, 거인과정에 의하여 감성적 반웅이 무시될 수 있다. 위에서 살펴본 바와 같이 소비자들이 자신이 느끼는 감성적 반웅이 특정 의사결정과 관련하여 적용가능성이나 적합성이 떨어진다고 생각한다면 '귀인과정(attribution processes)'을 통하여 그 영향력을 감소하려고 할 것이다(Schwarz and Clore 1983). 예를 들어 소비자들이 톡정 점포에 대하여 “친절하기는 한데..., 혹은 분위기가 좋기는 한대...” 등의 느낌을 받기도 한다. 더구나 본인들이 감성적 반옹에 의하여 영향을 받지 않은 상황에서도 잘못된 귀인과정을 거칠 수 있기 때문에 감성적 반응이 유발되지 않은 상황보다도 오히려 낮은 평가를 내릴 수 있다.

마지막으로 감성적 경험을 강조하는 연구들은 대체로 긍정적인 감성 상태를 원용하고 있는데 이러한 상태가 해당 브랜드의 정보처리에 부정적 영향을 미칠 가능성도 
있다(Schwarz and Bless 1991). 특히 상당한 수준의 정보처리가 필요한 브랜드나 후발주자로서 선발 브랜드의 결정올 언급해야 하는 상황에서는 긍정적인 무드 상태가 자신의 메시지률 전달하는 데에 오히려 장애요인이 될 수 있다.

\section{2 .2 총체적 경험}

총체적 경험은 이성, 감성, 감각 등 여러 가지 요소들이 복합적으로 결합되어 있으면서도 마치 하나인 것처럼 일관성과 밀착성(coherence)가 있는 게시탈트적인 경험올 의미하곤 한다(Schmitt 1999). 일단 브랜드에 대하여 이러한 경험을 제공할 수 있게 된다면 마케팅 담당자로서는 더할 나위 없이 반가운 일이다. 하지만, 과연 어떻게 이런 유형의 경험을 제공할 수 있는가라는 과제가 남아있다. 여러 경험 요소들을 복합하여 사용할 때에는 다음과 같은 사항을 고려할 필요가 있다.

우선, 단순히 여러 요소들을 복합하려는 마케팅 프로그램을 수행 할 경우에는 소비자에게 명확한 이미지를 전달하지 못하고 오히려 혼란만 줄 가능성도 있다. Park, Jarworski, McInnis 둥의 연구(1986)는 효과적인 포지셔넝을 위하여 컨셉의 일관성을 유지할 것을 강력하게 권하고 있다. 또한, Schmitt 둥 실무적 연구들의 제안은 특정 상황에서는 긍정적 감정이 정보처리에 부정적인 영향을 미치기도 한다는 점을 제시한 여러 연구들의 결과를(Adaval 2001, Schwarz 1998, Schwarz and Clore 1996, Wyer, Clore, and Isbell 1999) 간과하고 있는 것으로 보인다.

또한, 감성, 감각, 이성 둥 다양한 요소를 이용하여 복합적인 이미지를 전달하고자 할 때에는 상당한 수준의 마케팅 비용이 수반될 뿐만 아니라 그 효과도 의문시될 수 있다. 마케팅 비용이 존재하지 않는다면 이미지의 혼란을 걱정할 필요가 없는 조건에서는 다양하고 풍부한 브랜드 이미지를 구축하는 것이 바람직할 수 있다. 하지만 비용과 효율올 고려해야 할 뿐만 아니라 위에서 언급한 이미지의 혼란까지 유발할 수 있는 점을 주의할 필요가 있다.

\section{6. 결론}

기업에서는 브랜드관리를 다양한 접근방법을 통하여 수행할 필요가 있으며, 최근 학계나 실무계 모두 이러한 다양성에 초점을 맞추고 있다(안광호, 이진용 1997, Fombrun and van Riel 1997). 다양한 브랜드관리 방식의 하나로 경험적 접근의 기여도를 살펴보는 것은 대단히 의미가 있다. 이들 연구들이 브랜드관리의 관점을 넓히고 다양하고 신선한 브랜드 구축 방법을 제시했다는 점을 높이 평가할 수 있다.

한편, 브랜드관리는 단순히 다양성만을 강조하는 것이 아니라 체계성을 요구하고 있다. 기업들은 효율적이고 체계적인 브랜드 관리 방법을 개발하여 마케팅 할동의 지침으로 활용해야 한다. 대부분의 경험적 접근방법이 아직은 채계성을 제대로 갖추지 못하고 있어 '기존의 마케팅 방식을 대체한다는 식의 지나친 낙관론'(Pine and Gilmore 1998, Schmitt 1999)은 크게 과장된 측면이 있다. 경험적 접근방법의 상당부분은 아직 실증적, 이론적 체계가 부족하거나, 실무적으로 적용할 수 있는 조건이 제한적이다(Schwarz and Clore 1996, Wyer et al. 1999). 
더구나, 실무 취향의 경험적 접근방법들은 최근 심리학 분야에서 인상적인 연구성과를 보이고 있는 감성적 경험에 대한 체계적인 연구 성과들(예를 들어, Cacioppo and Gardner 1999, Schwarz and Clore 1983, 1999, Wyer, Clore, and Isbell 1999, Zajonc 1998 둥)을 거의 반영하고 있지 못한 것으로 판단된다(이에 대한 자세한 논의는 본 논문의 '4.2. 감성적 경험'을 참조하시오). 감성과 이성은 서로 명확하게 구분되는 별개의 과정이 아니라 서로 상호작용하고 상황에 따라서 각 변수의 상대적인 영향력이 달라질 수 있는 것이다. 이러한 연구들에 의하면 경험의 개별 단위나 총체적 경험 등의 개념은 아직 재대로 정립되어 있는 것이 아닐 뿐만 아니라 때에 따라서는 인간의 의사결정과정에서 나타나는 여러 변수간의 관계 규명을 위한 논점을 크게 흐릴 소지마저 있다.

경험적 접근방법은 이론적으로 이미 잘 정리되어 있는 브랜드 구축과 관련된 인지적 과정이나 브랜드 인지도, 이미지 등의 기존 연구에 대하여 '보완적 역할'을 수행하면서 '브랜드 구축 방법의 시야'를 넓힌다는 점에서 의의가 있다. 


\section{<참고문헌>}

김완석(1995), “특정 감정에 소구하는 광고의 효과기재," 광고연구, 가을호, 9-34.

안광호, 이진용(1997), 브랜드 파워, 한언.

양윤, 최훈희(2002), “무드와 제품범주에 따른 다양성 추구 행동과 무드와 다양성

추구경향성에 따른 정보탐색 행동," 광고학연구, 13(3), 71-102.

이유재(2000), “고객만족에 관한 종합적 고찰," 소비자학연구, 11(1), 139-166.

이진용 (2003), "브랜드 경험에 대한 개념적 고찰 및 실무적 시사점," 소비자학연구, 14(2), 215-242.

이학식, 임지훈(2002), “소비 관련 감정척도의 개발," 마케팅연구, 17(3), 55-91.

Aaker, David (1995), Building Strong Brands, Free Press.

Aaker, David and Erich Joachimsthaler (2000), Brand Leadership, Free Press.

Adaval, Rashimi (2001), "Sometimes It Just Feels Right: The Differential Weighting of Affect-Consistent and Affect-Inconsistent Information," Journal of Consumer Research, Vol. 28, June, 1-17.

Ariely, Dan and Ziv Carmon (2000), "Gestalt Characteristics of Experienced Profile," Journal of Behavioral Decision Making, 191-201.

Beggan, James K. (1992), "On the Social Nature of Nonsocial Perception: The Mere Ownership Effect," Journal of Personality and Social Psychology, Vol. 62, February, 229-237.

Berkowitz, Leonard (1993), “Toward a General Theory of Anger and Emotional Aggression: Implications of the Cognitive-Neoassociationalistic Perspectives for the Analysis of Anger and Other Emotions," in Advances in Social Cognition, Vol. 6, ed. Robert S. Hyer and Thomas K. Srull, Hillsdale, NJ: Erlbaum, 1-46.

Bettman, James (1979), An Information Processing Theory of Consumer Choice, Addison Wesley.

Bet tman, James. R., Marian F. Luce, and John W. Payne (1998), "Construct ive Consumer Choice Processes," Journal of Consumer Research, Vol. 25, 187-217.

Bitner, Mary Jo (1992), "Servicescapes: The Impact of Physical Surroundings on Consumers and Employees," Journal of Marketing, vol. 56, April, 57-71.

Blackston, Max (1992), "Observations: Building Brand Equity by Managing the Brand's Relationship," Journal of Advertising Research, May/June, 79-83.

Bower, G. H. (1991), "Mood Congruity of Social Judgment," in J. Forgas (ed.), Emot ion and Social Judgment, 31-53, Oxford: Pergamon.

Carpenter, Phil (1999), eBrands, Boston, MA: HBS Press.

Cacioppo, John T. and Wendi L. Gardner (1999), "Emotion," in Susan Fiske (ed.), Annual Review of Psychology, Vol, 50, 191-214, Stanford, CA: Annual Reviews, 184210 .

Chaudhuri, Arjun and Morris B. Holbrook (2001), "The Chain of Effects from Brand Trust and Brand Affect to Brand Performance: the Role of Brand Loyalty," Journal of Marketing, Vol. 65, April, 81-93. 
Clore, Gerard, L. Norbert Schwarz and M. Conway (1994), "Affective Causes and Consequences of Social Information Processing," in R.S. Hyer Jr. and T. K. Srull (eds.) Handbook of Social Cognition, $2^{\text {nd }}$ edition, Vol.1, 323-418, Hillsdale, NJ: Erlbaum.

Cohen, Joel B. and Charles S. Areni (1991), "Affect and Consumer Behavior," in Thomas S. Robertson and Harold H. Kassarjian (eds.), Handbook of Consumer Behavior, 188-240, Englewood Cliffs, NJ: Prentice Hall.

Csikszentmihalyi, Mihaly (1975), Beyond Boredom and Anxiety, San Francisco, CA: Jossey-Bass.

Csikszentmihalyi, Mihaly (1990), Flow: the Psychology of Optimal Experience, New York: Harper and Row.

Eliashberg, Jehoshua and Mohanbir S. Sawhey (1994), "Modeling Goes to Hollywood: Predicting Individual Difference in Movie Enjoyment," Management Science, 9(September), 1151-73.

Feldman, Jack M. and John G. Lynch, Jr. (1988), "Self-Generated Validity and Other Effects of Measurement on Belief, Attitude, Intention, and Behavior," Journal of Applied Psychology, Vol. 73, August, 421-435.

Fiske, Susan T., and Shelley E. Taylor (1984), Social Cognition, New York: Random House.

Florer, Faith L. and Gordon Allen (2000), "Feeling of Knowing in the Ranschberg Effect," American Journal of Psychology, 113, 2, 179-198.

Fombrun, Charles and Cees van Riel (1997), "The Reputational Landscape," Corporate Reputation Review, 1. 5-13.

Ford, Gary T., Darlene B. Smith, and John L. Swasy (1990), "Consumer Skepticism of Advertising Claims: Testing Hypotheses from Economics of Information," Journal of Consumer Research, Vol. 16, March, 433-441.

Fournier, Susan (1994), "A Consumer-Brand Relationship Framework for Strategic Brand Management," Unpublished Ph.D. Dissertation, University of Florida.

Fournier, Susan (1998), "Consumers and Their Brands: Developing Relationship Theory in Consumer Research," Journal of Consumer Research, 34(March), 343-373.

Fournier, Susan, Susan Dobscha, and David Glen Mick (1998), "Preventing the Premature Death of Relationship Marketing, ," Harvard Business Review, Vol. 76. January/February, 42-51.

Fournier, Susan, and David Glen Mick (1999), "Rediscovering Satisfaction," Journal of Marketing, Vol. 63, October, 5-23.

Gollwitzer, Peter M. and Gordon B. Moskowitz (1996), "Goal Effects on Action and Cognition," in E. Tory Higgins and Arie W. Kruglanski (eds.), Social Psychology, Handbook of Basic Principles, New York, NY: the Guilford Press, 361-399.

Gruen, Thomas W., John O.Summers, and Frank Acito (2000), "Relationship Marketing Activities, Commitment, and Membership Behaviors in Professional Associations," Journal of Marketing, Vol. 64, July, 34-49. 
Henderson, Pamela W. and Joseph A. Cote (1998), "Guidelines for Selecting and Modifying Logos," Journal of Marketing, Vol. 62, Apri1, 14-30.

Herr, Paul M., Frank R. Kardes, and John Kim (1991), "Effects of Word-of-Mouth and Product-Attribute Information on Persuasion: An Accessibility-Diagnosticity Perspective," Journal of Consumer Research, Vol. 17, March, 454-462.

Higgins, E. Tory (1996), "Knowledge Activation: Accessibility, Applicability, and Salience," in E. Tory Higgins and Arie W. Kruglanski (eds.), Social Psychology, Handbook of Basic Principles, New York, NY: the Guilford Press, 133-168.

Hirshman, Elizabeth C. and Morris B. Holbrook (1982), "Hedonic Consumption: Emerging Concepts, Methods, and Propositions," Journal of Marketing, Vol. 46, Summer, 92-101. Hoch, Stephen J. (2002), "Product Experience Is Seductive," Journal of Consumer Research, Vol. 29, December, 448-454.

Hoffman, Donna L. and Thomas P. Novak (1996), "Marketing in Hypermedia ComputerMediated Environments: Conceptual Foundation," Journal of Marketing, Vol. 60, July, 50-68.

Holbrook, Morris and Elizabeth Hirshman (1982), "The Experiential Aspects of

Consumption: Consumer Fantasies, Feelings, and Fun," Journal of Consumer Research, Vo1. 9, September, 132-140.

Hurst, Mark (1999), Holiday '99 E-Commerce: Building the $\$ 6$ Billion Customer Experience Gap, Creat ive Good.

Kahneman, Daniel, B. L. Fredrickson, C. A. Schreiber and D. A. Redelmeier (1993), "When More Pain is Preferred to Less: Adding a Better End," Psychological Science, Vol. 4, 401-405.

Kahneman, Daniel, Jack L. Knetsch, and Richard Thaler (1990), "Experimental Tests of the Endowment Effect and the Coase Theorem," Journal of Political Economy, Vol. 99. December, 1325-1348.

Kahneman, Daniel and Jackie Snell (1992), "Predicting a Changing Taste: Do People Know What They Will Like?" Journal of Behavioral Decision Making, Vol. 5, July, 187-200.

Kapferer, Noel (1993), Strategic Brand Management, Kogan Page.

Keller, Kevin Lane (1987), "Memory Factors in Advertising," Journal of Consumer Research, 14(December). 316-333.

Keller, Kevin Lane (1993), "Conceptualizing, Measuring, and Managing Customer-Based Brand Equity," Journal of Market ing, 57(January), 1-22.

Keller, Kevin Lane (1998), Strategic Brand Management, Prentice Hall.

Keller, Kevin Lane and David A. Aaker (1997), "Managing the Corporate Brand: the Effects of Corporate Marketing Activity on Consumer Evaluations of $\mathrm{Br}$ and Extensions," Marketing Science Inst itute Working Paper.

Kempf, DeAnna S. and Russell N. Laczniak (2001), "Advertising's Influence on Subsequent Product Trial Processing," Journal of Advertising. Vol. 30. No. 3 , Fal1, 27-38. 
Kotler, Philip and Gary Armstrong (1996), Principles of Marketing, 7th edition, Prent ice Hall.

Lemon, Katherine N., Roland T, Rust and Valarie A. Zeithaml (2001), "What Drives Customer Equity," Marketing Management, Spring, 20-25.

Loftus, Elizabeth and Gregory R. Loftus (1980), "On the Permanence of Stored Information in the Human Brain," American Psychologist, 35(May), 409-420.

Loewenstein, George (2001), "The Creative Destruction of Decision Research," Journal of Consumer Research, Vol. 28, December, 499-505.

McAlexander, James H., John W. Shouten, and Harold F. Koenig (2002), "Building Brand Community," Journal of Marketing, 66 (January), 38-54.

McKenna, Regis (1991), Relationship Marketing, Addison Wesley.

Meloy, Margaret G. (2000), "Mood-Driven Distortion of Product Information," Journal of Consumer Research, Vol. 27, December, 345-359.

Munitz, Albert M., Jr. and Thomas C. 0' Guinn (2000), "Brand Community," Journal of Consumer Research, 27(3), 345-359.

Neelamegham, Ramya and Dipak Jain (1999), "Consumer Choice Process for Experience Goods: An Econometric Model and Analysis," Journal of Marketing Research, 36, August, $373-386$.

Nelson, Phillip (1970), "Information and Consumer Behavior," Journal of Political Economy, Vol. 78 March/April, 311-329.

Oliver, Richard L. (1999), "Whence Customer Loyalty?" Journal of Marketing, Vol. 63, Special Issue, 33-44.

Park, C. Whan, Bernard J. Jaworski, \& Deborah J. Mclnnis (1986), "Strategic Brand Concept Management," Journal of Marketing, 50(October), 135-145.

Park, C. Whan, Sandra Milberg, \& Robert Lawson (1991), "Evaluations of Brand Extensions: the Role of Product Feature Similarity and Brand Concept Consistency," Journal of Consumer Research, Vol. 18, September, 185-193.

Petty, Richard. E and John T. Cacioppo (1981), Attitudes and Persuasion: Classic and Contemporary Approaches, WCB Publishers.

Pham, Michel Tuan (1998), "Representativeness, Relevance, and the Use of Feelings in Decision Making," Journal of Consumer Research, Vol. 25, September, 144-159.

Pham, Michel Tuan, Joel B. Cohen, John W. Pracejus, and G. David Hughes (2001), "Af fect Monitoring and the Primacy of Feelings in Judgment," Journal of Consumer Research, Vol. 26, March, 167-188.

Pine II, B. Joseph and James H. Gilmore (1998), "Welcone to the Experience Economy," Harvard Business Review, July/August, 97-105.

Pine II, B. Joseph and James H. Gilmore (1999), The Experience Economy: Hork is Theatre and Every Business Stage, Boston. MA: Harvard Business School Press.

Pritchard, Mark P., Mark E. Havitz and Dennis R. Howard (1999), "Analyzing the Commitment-Loyalty Link in Service Contexts," Journal of the Academy of Marketing Science, Vol. 27, No. 3, 333-348. 
Richins, Marsha (1997), "Measuring Emotions in Consumption Experience," Journal of Consumer Research. Vol. 24, September, 127-146.

Schmitt, Bernd (1999), Experiential Marketing, Free Press.

Schmitt, Bernd (2003), Customer Experience Management: A Revolutionary Approach to Connecting with Your Customers, John Wiley \& Sons.

Schmitt, Bernd and Alex Simonson (1997), Marketing Aesthetics, Free Press.

Schwarz, Norbert (1998), "Warmer and More Social: Recent Developments in Cognitive Social Psychology," Annual Review of Sociology, 239-264.

Schwarz, Norbert and H. Bless (1991), "Happy and Mindless, but Sad and Smart? The Impact of Affective States on Analytic Reasoning," in J. Forgas (ed.), Emotion and Social Judgment, 55-71, Oxford: Pergamon.

Schwarz, Norbert and Gerald L. Clore (1983), "Mood, Misattribution, and Judgment of Well-Being: Informative and Directive Functions of Affective States," Journal of Personality and Social Psychology, Vol. 45, September, 513-524.

Schwarz, Norbert and Gerald L. Clore (1996), "Feeling and Phenomenal Experiences," in E. Tory Higgins and Arie W. Kruglanski (ed.s), Social Psychology, Handbook of Basic Principles, New York: the Guilford Press, 433-465.

Shiv, Baba and Alexander Fedorkhin (1999), "Heart and Mind in Conflict: The Interplay of Affect and Cognition in Consumer Decision Making," Journal of Consumer Research, Vol. 26, 278-292.

Smith, Robert E. and William R. Swinyard (1982), "Information Response Models: An Integrated Approaches," Journal of Marketing, Vol. 46, Winter, 81-93.

Smith, Robert E. and William R. Swinyard (1988), "Cognitive Response to Advertising and Trial: Belief Strength, Belief Confidence and Product Curiosity," Journal of Advertising, Vol. 17, No. 3, 3-14.

Soman, Dilip (2003), "Prospective and Retrospective Evaluations of Experience: How You Evaluate an Experiences Depends on When You Evaluate It," Journal of Behavioral Decision Making, 16, 35-52.

Strahilevitz, Michal and George Loewenstein (1998), "The Effect of Ownership History on the Valuation of Objects," Journal of Consumer Research, Vol. 25, December, 276-289.

Thaler, Richard (1999), "Mental Accounting Matters," Journal of Behavioral Decision Making, 12, 183-206.

Vavra, Terry (1992), Aftermarketing: How to Keep Customers for Life through Relat ionship Marketing, Homewood, IL: Business One Irwin.

Veryzer, Roberts W. and J. Wesley Hutchinson (1998), "The Influence of Unity and Prototypicality on Aesthetics Responses to New Product Designs," Journal of Consumer Research, Vol. 24, June, 374-394.

Wegner, Daniel M. and John A. Bargh (1998). "Control and Automaticity in Social Life," in Daniel T. Gilbert, Susan T. Fiske, and Gardner Lindzey (eds.), Handbook of Social Psychology, $4^{\text {th }}$ edition, 446-496. New York, NY: McGraw Hill Companies. 
Wilkie, William L. (1994), Consumer Behavior, New York: John Wiley \& Sons.

Wright, Alice A. and John G. Lynch, Jr. (1995), "Communication Effects of Advertising Versus Direct Experience When Both Search and Experience Attributes Are Present," Journal of Consumer Research, Vol. 21, March, 708-718.

Wyer, Robert S. Jr., Gerald L. Clore, and Linda M. Isbell (1999), "Affect and Information Processing," in Mark P. Zanna (ed.), Advances in Experimental Social Psychology, San Diego, CA: Academic Press, 1-77.

Zajonc, Robert B. (1998), "Emotions," in Daniel T. Gilbert, Susan T. Fiske, and Gardner Lindzey (eds.). Handbook of Social Psychology, $4^{\text {th }}$ edition, 591-634, New York: New York, McGraw Hill Companies. 